\title{
Fibrillar Amyloid- $\beta$-Activated Human Astroglia Kill Primary Human Neurons via Neutral Sphingomyelinase: Implications for Alzheimer's Disease
}

\author{
Arundhati Jana and Kalipada Pahan \\ Department of Neurological Science, Rush University Medical Center, Chicago, Illinois 60612
}

\begin{abstract}
Glial activation plays an important role in the pathogenesis of various neurodegenerative disorders including Alzheimer's disease. However, molecular mechanisms by which activated glia could kill neurons are poorly understood. The present study underlines the importance of neutral sphingomyelinase (N-SMase) in mediating the damaging effect of fibrillar amyloid- $\beta$ 1-42 (A $\beta_{1-42}$ ) peptideactivated astroglia on neurons. In transwell experiments, soluble products released from activated primary human astroglia induced the activation of neutral sphingomyelinase (N-SMase), production of ceramide, and cell death in primary human neurons. Protection of neurons from cytotoxic effects of activated astroglia by antisense knockdown of N-SMase, but not acidic sphingomyelinase (A-SMase), suggests that soluble products released from activated astroglia kill neurons via N-SMase but not A-SMase. Next we examined the role of $\mathrm{N}$-SMase in the activation of human astroglia. Interestingly, knockdown of N-SMase, but not A-SMase, by either antisense oligonucleotides or chemical inhibitor, prevented the induction of proinflammatory molecules [tumor necrosis factor- $\alpha$, inducible nitric oxide synthase, interleukin- $1 \beta$ (IL-1 $\beta$ ), and IL-6] and the activation of nuclear factor- $\kappa \mathrm{B}$ in $\mathrm{A} \beta_{1-42}$-activated astroglia. Subsequently, fibrillar $\mathrm{A} \beta$ peptides also induced the activation of $\mathrm{N}$-SMase and ceramide in vivo in mouse cortex. Most importantly, antisense knockdown of $\mathrm{N}$-SMase, but not A-SMase, decreased the activation of astroglia and protected neurons from fibrillar A $\beta$ toxicity in vivo in the cortex. Together, it is apparent that both the activation of astroglia by $\mathrm{A} \beta$ and that the cytotoxicity of activated astroglia on neurons depend on N-SMase.
\end{abstract}

\section{Introduction}

Alzheimer's disease (AD) (Martin, 1999) is a neurodegenerative disorder resulting in progressive neuronal death and memory loss. Neuropathologically, the disease is characterized by neurofibrillary tangles and neuritic plaques. Neurofibrillary tangles are composed of the hyperphosphorylated tau protein (Braak et al., 1994). On the other hand, neuritic plaques are mainly composed of aggregates of amyloid- $\beta$ (A $\beta$ ) protein, a 40-43 amino acid proteolytic fragment derived from the amyloid precursor protein that is overexpressed in AD (Martin, 1999). Histopathologically, this disease is characterized by infiltration of inflammatory cells into the CNS, gliosis, and neuronal apoptosis (Stalder et al., 2005; Simard et al., 2006; Town et al., 2008).

Although deposition of $\mathrm{A} \beta$ peptides is one of the primary causes of neuronal loss in $\mathrm{AD}$ (Hsiao et al., 1996), mechanisms by which $\mathrm{A} \beta$ causes neuronal loss are mostly unknown. Several lines of evidence suggest that neurons are killed through neurotoxic molecules elaborated from glial activation. Consequently, activated astrocytes and microglia are characteristically found in

Received March 10, 2010; revised July 2, 2010; accepted July 26, 2010.

This work was supported by Alzheimer's Association Grant IIRG-07-58684 and National Institutes of Health Grant NS39940-10S1.

Correspondence should be addressed to Dr. Kalipada Pahan, Department of Neurological Science, Rush University Medical Center, 1735 West Harrison Street, Chicago, IL 60612. E-mail: Kalipada_Pahan@rush.edu.

DOI:10.1523/JNEUROSCI.1243-10.2010

Copyright $\odot 2010$ the authors $\quad$ 0270-6474/10/3012676-14\$15.00/0 abundance near amyloid plaques in $\mathrm{AD}$ and in mouse models of $\mathrm{AD}$, and amyloid peptides have been reported as glial activators in the presence of an immunological cofactor (Meda et al., 1995; Tan et al., 1999, 2002). Activated glia are also found to increase substantially in the hippocampus and neocortex of the aging brain (Nichols, 1999). Consistently, microinjection of preaggregated $\mathrm{A} \beta_{1-42}$ peptides into the nucleus basalis of the rat produces a congophilic deposit followed by microglial and astrocyte activation and a strong inflammatory reaction surrounding the dystrophic neuritis (Giovannini et al., 2002; Jantaratnotai et al., 2003).

Therefore, controlling glial activation and, hence, inflammation is of great therapeutic interest in mitigating neuronal cell death in different neurological disorders including AD. Because ceramide, the lipid second messenger molecule, produced from the degradation of sphingomyelin by sphingomyelinases (neutral and acidic) induces apoptosis and cell death in various cell types, including glial and neuronal cells (Brugg et al., 1996; Hannun, 1996; Wiesner and Dawson, 1996; Keane et al., 1997; Singh et al., 1998; Pettus et al., 2002), we decided to investigate the neutral sphingomyelinase (N-SMase)-ceramide pathway in $\mathrm{A} \beta$ activated glia-mediated neuronal death. Here, we present the evidence that $\mathrm{A} \beta$ plus interleukin- $1 \beta(\mathrm{A} \beta+\mathrm{IL}-1 \beta)$-activated astrocytes induce the activation of sphingomyelinases and the production of ceramide in human primary neurons. We also show that the activation of neutral sphingomyelinase, but not acidic 

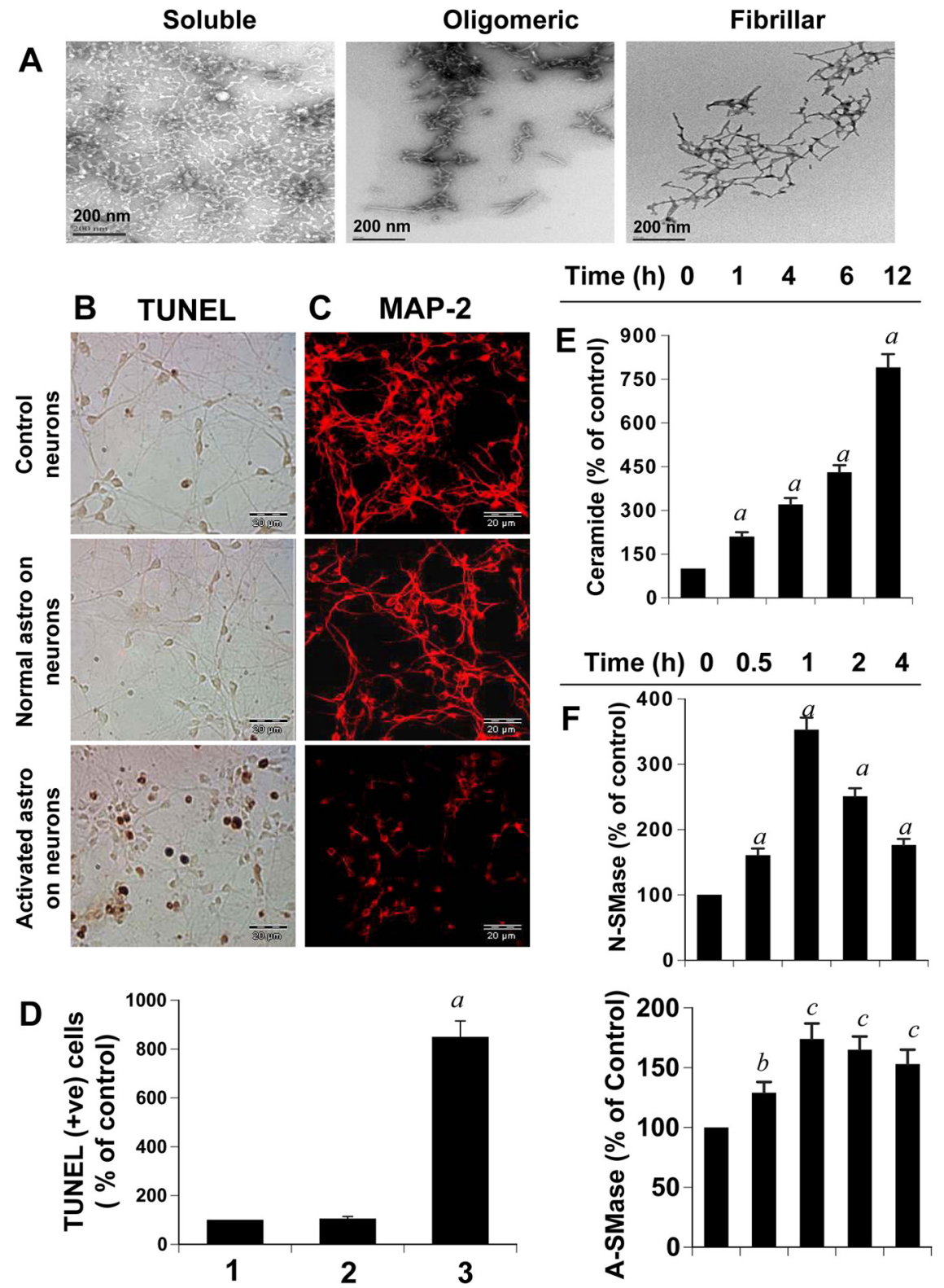

Figure 1. Activated primary human astrocytes induce apoptosis and the activation of the N-SMase-ceramide pathway in primary human neurons in neuron-astrocyte transwell cultures. $A$, Morphology of oligomeric and fibrillar form of $\mathrm{A} \beta_{1-42}$ peptides was examined by transmission electron microscopy. $\boldsymbol{B}$, Primary human astrocytes seeded in inserts were stimulated with a combination of $1 \mu \mathrm{m}$ fibrillar $A \beta$ and $10 \mathrm{ng} / \mathrm{ml} \mathrm{IL-1} \beta$ in serum-free media. After $24 \mathrm{~h}$, media were removed and inserts with activated astrocytes were placed on coverslips containing primary neurons for $6 \mathrm{~h}$ followed by TUNEL. C, After $18 \mathrm{~h}$ of treatment of neurons with activated astrocytes, cells were immunostained with MAP-2. D. TUNEL-positive cells were counted manually in four different images of each of three coverslips by three individuals blinded to the experiment. Values obtained from the control group (1) served as $100 \%$, and data obtained from other two groups, i.e., the normal astrocyte-neuron group (2) and the activated astrocytes-neuron group (3) were calculated as a percentage of control accordingly. Results are the mean \pm SD of three different experiments. ${ }^{a} p<0.001$ versus control. Activated astrocytes were placed on human neurons and further incubated for different time intervals. $\boldsymbol{E}$, Lipids were extracted from neurons at respective time points, and ceramide levels were determined. ${ }^{a} p<0.001$ versus $0 \mathrm{~h}$. $\boldsymbol{F}$, Activities of N-SMase and A-SMase were assayed in total cell extract of neurons. Control group served as $100 \%$, and data from other groups were expressed as a percentage of control. Results are the mean $\pm S D$ of three different experiments. ${ }^{a} p<$ 0.001 versus $0 \mathrm{~h} ; b_{p}<0.05$ versus $0 \mathrm{~h} ;{ }^{c} p<0.001$ versus $0 \mathrm{~h}$.

sphingomyelinase (A-SMase), plays a key role in neuronal apoptosis in response to neurotoxins released from activated astrocytes. Furthermore, blocking of astroglial activation by N-SMase inhibition prevented the release of neurotoxic substances. Subsequently, inhibition of astroglial N-SMase suppressed nuclear factor- $\kappa \mathrm{B}(\mathrm{NF}-\kappa \mathrm{B})$ activation in activated astroglia. The in vitro data were further substantiated by in vivo findings where we found that antisense oligo- nucleotides (ASOs) against N-SMase prevented astrogliosis and microgliosis and protected neurons in the cortex of $\mathrm{A} \beta$ injected C57BL/6 mice.

\section{Materials and Methods \\ Reagents}

Neurobasal medium and B27 supplement were purchased from Invitrogen. Fetal bovine serum and DMEM/F-12 were obtained from Mediatech. Human A $\beta$ peptides (1-42) and (42-1) were obtained from Bachem Bioscience. Glial fibrillary acidic protein (GFAP) was purchased from Santa Cruz Biotechnology. Phosphorothioate-labeled antisense and scrambled oligodeoxynucleotides were synthesized in the DNA-synthesizing facility of Invitrogen.

\section{Isolation of primary human neurons}

Human primary neurons were prepared as described previously (Jana and Pahan, 2004a,b; Jana et al., 2007). All of the experimental protocols were reviewed and approved by the Institutional Review Board of the Rush University Medical Center. Briefly, 11- to 17week-old fetal brains obtained from the Human Embryology Laboratory (University of Washington, Seattle, WA) were dissociated by trituration and trypsinization $(0.25 \%$ trypsin in PBS at $37^{\circ} \mathrm{C}$ for $\left.15 \mathrm{~min}\right)$. The trypsin was inactivated with $10 \%$ heat-inactivated fetal bovine serum (Mediatech). The dissociated cells were filtered through 380 and $140 \mu \mathrm{m}$ meshes (Sigma) and pelleted by centrifugation. The cell pellet was washed once with PBS and once with Neurobasal medium containing $2 \%$ B27 and 1\% antibiotic-antimycotic mixture (Sigma). In the first step, neurons were enriched by allowing the cells $\left(3 \times 10^{6} / \mathrm{ml}\right)$ to adhere to poly-D-lysine-coated plates or coverslips for $5 \mathrm{~min}$. Nonadherent cells were removed, and adherent cells (mostly neurons) were further treated with $10 \mu \mathrm{M}$ arabinosylcytosine to prevent the proliferation of dividing cells. After $10 \mathrm{~d}$ of Ara-C treatment, the cells were used for this study. More than $98 \%$ of this preparation was positive for microtubuleassociated protein-2 (MAP-2), a marker for neurons.

\section{Preparation of primary human astrocytes}

Primary human astrocytes were prepared as described previously (Jana et al., 2005, 2007; Saha et al., 2007). Briefly, human CNS tissue (Human Embryology Laboratory, University of Washington, Seattle, WA) from each specimen was processed separately and independently, as were subsequent cell cultures. There was no pooling of CNS tissue from distinct specimens. All of the experimental protocols were reviewed and approved by the Institutional Review Board of the Rush University Medical Center. By immunofluorescence assay, these cultures homogeneously expressed GFAP (Liu et al., 2002).

Astrocyte-neuron transwell study

Primary human astrocytes were grown to confluency on inserts. After $24 \mathrm{~h}$ of stimulation by the combination of $\mathrm{A} \beta(1 \mu \mathrm{M})$ and IL- $1 \beta$ (10 
$\mathrm{ng} / \mathrm{ml})$, inserts were washed thrice with HBSS and then placed onto the wells containing primary human neurons. Therefore, in this transwell model, although neurons and astrocytes face each other, they are separable, and the effect of soluble factors released from activated astrocytes on neurons can be studied, allowing analysis of neuronal and glial populations separately.

\section{Preparation of fibrillar $A \beta$}

Fibrillar $\mathrm{A} \beta_{1-42}$ and control reverse peptide $\mathrm{A} \beta_{42-1}$ (Bachem Bioscience) were prepared by incubating freshly solubilized peptides at $50 \mu \mathrm{M}$ in sterile distilled water at $37^{\circ} \mathrm{C}$ for $5 \mathrm{~d}$ (Pike et al., 1993). On the other hand, oligomeric $\mathrm{A} \beta_{1-42}$ was prepared after incubation at $37^{\circ} \mathrm{C}$ for $2 \mathrm{~d}$ (for morphology of oligomeric and fibrillar forms of $\mathrm{A} \beta_{1-42}$, see Fig. 1A).

\section{Treatment of primary neurons}

During treatment with fibrillar $\mathrm{A} \beta$ peptides, cells were incubated in Neurobasal medium containing 2\% B27 supplement without antioxidant (Invitrogen).

\section{Assay of neutral and acidic sphingomyelinases}

Activities of SMase(s) were assayed as described previously by Jana and Pahan (2004a,b, 2007). Briefly, after treatment, the cells were washed with PBS, harvested in PBS, divided into two halves, and centrifuged. The fraction for N-SMase was resuspended in buffer A (100 mu Tris- $\mathrm{HCl}, \mathrm{pH} 7.4,0.1 \%$ Triton X-100, 1 mM EDTA, and protease inhibitors), and the cell suspension was sonicated and centrifuged at $500 \times g$ at $4^{\circ} \mathrm{C}$ for $5 \mathrm{~min}$. The supernatant was used as the enzyme source for N-SMase. The reaction mixture contained enzyme preparation in buffer A containing $5 \mathrm{nmol}$ of $\left[{ }^{14} \mathrm{C}\right]$ sphingomyelin, $5 \mathrm{nmol}$ of phosphatidylserine, $5 \mathrm{~mm}$ dithiothreitol, and $5 \mathrm{~mm} \mathrm{MgCl}$ in a final volume of $100 \mu$ l. Similarly, the fraction for A-SMase was resuspended in buffer B ( $100 \mathrm{~mm}$ sodium acetate, $\mathrm{pH} 5.0,0.1 \%$ Triton $\mathrm{X}-100$, and protease inhibitors). The cell suspension was sonicated and centrifuged. The supernatant was used as the source of A-SMase. The activity of A-SMase was measured in $100 \mu \mathrm{l}$ of reaction mixture consisting of the enzyme preparation in buffer $\mathrm{B}$ and $5 \mathrm{nmol}$ of $\left[{ }^{14} \mathrm{C}\right]$ sphingomyelin. The enzyme reaction was initiated by the addition of $50 \mu$ l of substrate and stopped by the addition of $1.5 \mathrm{ml}$ of chloroform: methanol $(2: 1, \mathrm{v} / \mathrm{v})$ and $0.2 \mathrm{ml}$ of water. After vortexing and phase separation, the aqueous phase was removed for counting.

Quantification of ceramide levels by diacylglycerol kinase assay After treatment, lipids were extracted from cells as described previously (Pahan et al., 1998, 2000a). Ceramide content was quantified using diacylglycerol (DAG) kinase and $\left[\gamma^{-}{ }^{32} \mathrm{P}\right]$ ATP as described previously (Pahan et al., 1998, 2000). Briefly, dried lipids were solubilized in $20 \mu$ l of an octyl $\beta$-D-glucoside/cardiolipin solution (7.5\% octyl $\beta$-D-glucoside and $5 \mathrm{~mm}$ cardiolipin in $1 \mathrm{~mm}$ diethylenetriaminepentaacetic acid) by sonication in a sonicator bath. The reaction was then performed in a final volume of $100 \mu \mathrm{l}$ containing the $20 \mu \mathrm{l}$ of sample solution, $50 \mathrm{~mm}$ imidazole $\mathrm{HCl}, \mathrm{pH}$

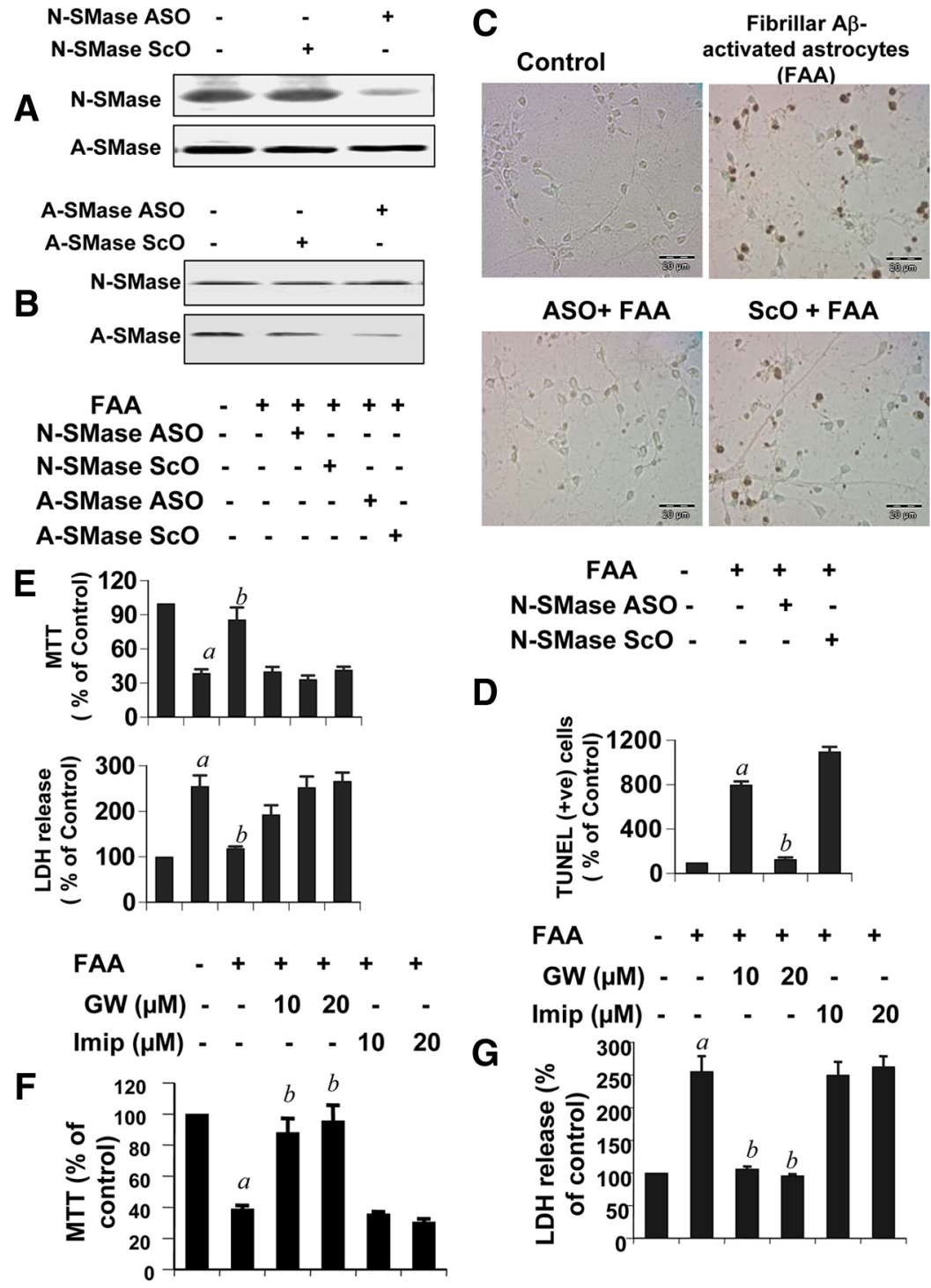

Figure 2. Antisense or chemical knockdown of N-SMase, but not A-SMase, protects neurons from A $\beta$-activated primary human astrocytes in astrocyte-neuron transwell cultures. $A, B$, Primary human neurons were incubated with $A S O s$ and $S c 0$ s against N-SMase $(\boldsymbol{A})$ and A-SMase $(\boldsymbol{B})$. After $48 \mathrm{~h}$, neurons were analyzed for protein expression of N-SMase and A-SMase. $\boldsymbol{C}$, Primary human astrocytes seeded in inserts were stimulated by the combination of $A \beta$ and IL- $1 \beta$ as described above. After $24 \mathrm{~h}$, media were removed, and inserts were washed and placed on neurons that were already pretreated for $40 \mathrm{~h}$ with $1 \mu \mathrm{m} \mathrm{ASO}$ or Sc0 against N-SMase and A-SMase. After $6 \mathrm{~h}$ of treatment with activated astrocytes, apoptotic events in neurons were detected by TUNEL. $\boldsymbol{D}$, TUNEL-positive cells were counted manually in four different images of each of three coverslips by three individuals blinded to the xperiment. $\boldsymbol{E}$, After $18 \mathrm{~h}$ of stimulation, cell viability was examined by the metabolism of MTT and the release of LDH. Activated astrocytes were placed on neurons that were pretreated with different concentrations of GW4869 (GW) and imipramine. $\boldsymbol{F}, \mathbf{G}$, Cell viability was checked by MTT $(\boldsymbol{F})$ and LDH (G). Values obtained from the control group served as $100 \%$, and data obtained in other groups were calculated as a percentage of control accordingly. Results are the mean $\pm S D$ of three different experiments. ${ }^{a} p<$ 0.001 versus control; $b<0.001$ versus FAA. FAA, Fibrillar $A \beta+\mathrm{IL}-1 \beta$-activated astrocytes.

6.6, $50 \mathrm{~mm} \mathrm{NaCl}, 12.5 \mathrm{~mm} \mathrm{MgCl}$, 1 mm EGTA, 2 mM dithiothreitol, 6.6 $\mu \mathrm{g}$ of DAG kinase, and $1 \mathrm{~mm}\left[\gamma^{-}{ }^{32} \mathrm{P}\right]$ ATP (specific activity of $1-5 \times 10^{5}$ $\mathrm{cpm} / \mathrm{nmol}$ ) for $30 \mathrm{~min}$ at room temperature. The labeled ceramide-1phosphate was resolved with a solvent system consisting of methyl acetate: $n$-propyl alcohol/chloroform/methanol/ $0.25 \% \mathrm{KCl}$ in water/acetic acid (100:100:100:40:36:2). A standard sample of ceramide was phosphorylated under identical conditions and developed in parallel. Both standard and experimental samples had an identical $R_{\mathrm{F}}$ value $(0.46)$. Quantification of ceramide-1-phosphate was performed by autoradiography and densitometric scanning using a Fluor Chem 8800 imaging system (Alpha Innotech). Values are expressed either as arbitrary units (absorbance) or as a percentage of control, considering 
control as $100 \%$. Statistical comparisons were made using one-way ANOVA followed by Student's $t$ test.

\section{Assay for NO synthesis}

Synthesis of NO was determined by assay of culture supernatants for nitrite, a stable reaction product of $\mathrm{NO}$ with molecular oxygen, using Griess reagent as described previously (Jana et al., 2001; Liu et al., 2002).

\section{Immunostaining}

Coverslips containing 200-300 cells $/ \mathrm{mm}^{2}$ were fixed with $4 \%$ paraformaldehyde for $20 \mathrm{~min}$ followed by treatment with cold ethanol $\left(-20^{\circ} \mathrm{C}\right)$ for 5 min and 2 rinses in PBS. The samples were blocked with $3 \%$ bovine serum albumin in PBS containing Tween 20 (PBST) for $30 \mathrm{~min}$ and incubated in PBST containing $1 \%$ bovine serum albumin and goat anti-MAP-2 (1:50), as described previously (Dasgupta et al., 2003b, 2004). After three washes in PBST (15 min each), the slides were further incubated with Cy5 (Jackson ImmunoResearch Laboratories). For negative controls, a set of culture slides were incubated under similar conditions without the primary antibodies. The samples were mounted and observed under a Bio-Rad MRC1024ES confocal laser-scanning microscope.

\section{GFAP and NeuN immunostaining}

Two days after microinjection, mice were perfused with $4 \%$ paraformaldehyde and their brains were processed for immunohistochemical studies. For double labeling of GFAP with inducible nitric oxide synthase (iNOS), sections $(6 \mu \mathrm{m})$ were incubated with polyclonal anti-GFAP (GFAP, 1000 dilution; Calbiochem) and anti-iNOS (iNOS, 1000 dilution; Calbiochem) for $24 \mathrm{~h}$ at $4^{\circ} \mathrm{C}$. After three washes in PBST (15 min each), slides were further incubated with Cy5 and Cy2 (Jackson ImmunoResearch Laboratories) secondary antibodies for $2 \mathrm{~h}$ at room temperature. For negative controls, a set of tissue sections was incubated under similar conditions without the primary antibodies. The samples were mounted and observed under a Bio-Rad MRC1024ES confocal laser-scanning microscope.

\section{Fragment end labeling of DNA}

Fragmented DNA was detected in situ by the terminal deoxynucleotidyl transferase (TdT)-mediated binding of $3^{\prime}-\mathrm{OH}$ ends of DNA fragments generated in response to fibrillar $\mathrm{A} \beta_{1-42}$, using a commercially available kit (TdT FragEL) from Calbiochem. Briefly, coverslips were treated with $20 \mu \mathrm{g} / \mathrm{ml}$ proteinase $\mathrm{K}$ for $15 \mathrm{~min}$ at room temperature and washed before terminal deoxynucleotidyl transferase staining.

\section{Cell viability measurement}

MTT assay. Mitochondrial activity was measured with the 3-(4, 5-dimethylthiazol-2-yl)-2, 5-diphenyltetrazolium bromide (MTT) assay (Sigma). The cells were grown on 24 -well culture plates with $500 \mu \mathrm{l}$ of medium and treated with various reagents according to the experimental design. At the end of the treatment period, $300 \mu \mathrm{l}$ of culture medium were removed from each well, and $20 \mu$ l of MTT solution $(5 \mathrm{mg} / \mathrm{ml})$ were added and incubated for $1 \mathrm{~h}$.

Lactate dehydrogenase measurement. The activity of lactate dehydrogenase ( $\mathrm{LDH})$ was measured using the direct spectrophotometric assay using an assay kit from Sigma.

Microinjection of $A \beta$ into the frontal cortex of C57BL/6 mice. C57BL/6 mice $(10-12$ weeks old $)$ were anesthetized with ketamine and xylazine and underwent cortical operations in a Kopf small animal stereotaxic instrument. Briefly, the animal was mounted in a stereotaxic frame on a heating blanket. Body temperature was maintained at $37 \pm 0.5^{\circ} \mathrm{C}$ during the time of surgery. A midsagittal incision was made to expose the cranium and a hole $<0.5 \mathrm{~mm}$ in diameter was drilled with a dental drill over the frontal cortex according to the following coordinates: $1.5 \mathrm{~mm}$ anterior to bregma, $1.5 \mathrm{~mm}$ lateral to bregma, and $1 \mathrm{~mm}$ ventral (see Fig. 9A). One microgram of either $\mathrm{A} \beta_{1-42}$ or $\mathrm{A} \beta_{42-1}$ in $2 \mu \mathrm{l}$ of saline was injected using a $5 \mu$ l syringe (Hamilton) over a period of $3 \mathrm{~min}$, and the needle was held in place for another $2 \mathrm{~min}$ before withdrawing it from the skull to prevent reflux up the needle tract. Similarly, control mice received $2 \mu \mathrm{l}$ of saline. During antisense treatment, $1 \mu \mathrm{g}$ of either ASO or scrambled oligonucleotide $(\mathrm{ScO})$ against
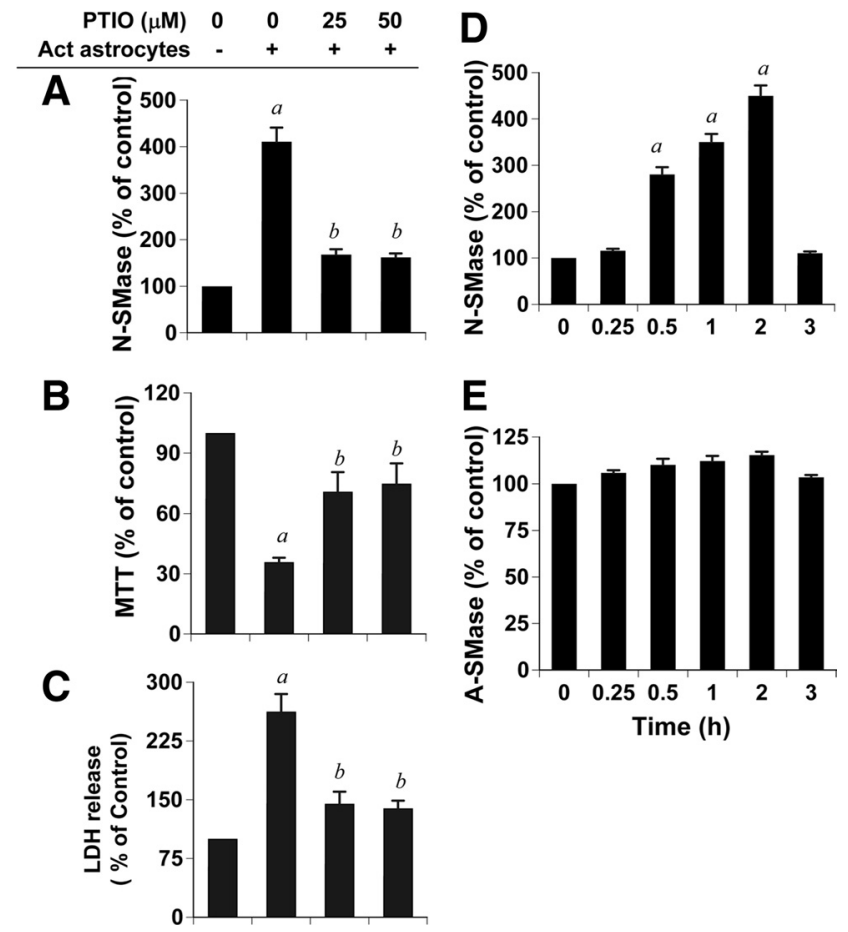

Figure 3. Role of nitric oxide in activated astrocyte-induced cell death in neurons. Primary human astrocytes seeded in inserts were stimulated by the combination of $A \beta$ and IL- $1 \beta$ as described above. After $24 \mathrm{~h}$, media were removed and inserts were washed and placed on neurons that were pretreated with PTIO for 30 min. $A$, After $1 \mathrm{~h}$, activity of N-SMase was measured in total cell extracts of neurons as described above. $\boldsymbol{B}, \boldsymbol{C}$, After $18 \mathrm{~h}$, neuronal viability was examined by the metabolism of MTT (B) and the release of LDH (C). Values obtained from the control group served as $100 \%$, and data obtained in other groups were calculated as a percentage of control accordingly. Results are the mean \pm SD of three different experiments. ${ }^{a} p<0.001$ versus control; $b_{p}<0.001$ versus activated astrocytes. $\boldsymbol{D}, \boldsymbol{E}$, Primary human neurons were treated with $25 \mu \mathrm{m}$ DETA-NONOate (an NO donor), and at different time points of treatment, activities of $\mathrm{N}$-SMase $(\boldsymbol{D})$ and A-SMase $(\boldsymbol{E})$ were monitored. ${ }^{a} p<0.001$ versus control (0h).

$\mathrm{N}$-SMase dissolved in $2 \mu \mathrm{l}$ saline was stereotaxically injected into the frontal cortex of C57BL/6 mice. After $24 \mathrm{~h}$ of ASO/ScO microinjection, $1 \mu \mathrm{g}$ of fibrillar $\mathrm{A} \beta_{1-42}$ in $2 \mu \mathrm{l}$ volume was again microinjected at the same site as described above. The incision was closed with surgical staples and covered with a mixture of Bacitracin and Hurricane ( $20 \%$ benzocaine).

Semiquantitative reverse transcriptase-coupled PCR. Total RNA was isolated from human primary astrocytes using RNA-Easy Qiagen kit following the manufacturer's protocol. To remove any contaminating genomic DNA, total RNA was digested with DNase. Semiquantitative reverse transcriptase-coupled (RT)-PCR was performed as described previously (Jana and Pahan, 2005) using oligo (dT) ${ }_{12-18}$ as primer and moloney murine leukemia virus reverse transcriptase (Clontech) in a 20 $\mu \mathrm{l}$ reaction mixture. The resulting cDNA was appropriately diluted, and diluted cDNA was amplified using Titanium Taq polymerase and the following primers for human proinflammatory genes: tumor necrosis factor- $\alpha$ (TNF- $\alpha ; 378 \mathrm{bp}$ ), sense, $5^{\prime}$-CTG AGT CGG TCA CCC TTC TCC AGC T- $3^{\prime}$; antisense, $5^{\prime}$-CCC GAG TGA CAA GCC TGT AGC CCA T-3'; IL-1 $\beta$ (263 bp), sense, 5'-GGA TAT GGA GCA AC A AGT GG-3'; antisense, $5^{\prime}$-ATG TAC CAG TTG GGG AAC T-3'; IL-6 (236 bp), sense, 5'-TTT TGG AGT TTG AGG TAT ACC TAG-3'; antisense, 5' -GCT GCG CAG AAT GAG ATG AGT TGT-3'; iNOS (368 bp), sense, 5' -CTG CAG ACA CGT GCG TTA CTC CAC C-3'; antisense, 5'-GCA GGG CGT ACC ACT TTA GCT CCA G-3'; glyceraldehyde-3-phosphate dehydrogenase (GAPDH; 300 bp), sense, 5'-GGT GAA GGT CGG AGT CAA CG-3'; antisense, 5' -GTG AAG ACG CCA GTG GAC TC-3'.

Amplified products were electrophoresed on a $1.8 \%$ agarose gels and visualized by ethidium bromide staining. Message for the GAPDH gene 
was used to ascertain that an equivalent amount of cDNA was synthesized from different samples.

Quantitative real-time PCR analysis. Quantitative real-time PCR analysis was performed using the ABI-Prism7700 sequence detection system (Applied Biosystems) using TaqMan Universal Master Mix and optimized concentrations of FAM-labeled probe, forward and reverse primers (Applied Biosystems) as described previously (Jana and Pahan, 2005). The mRNA expression of iNOS was normalized to the label of GAPDH mRNA. Data were processed by the ABI Sequence Detection System 1.6 software and analyzed by ANOVA.

Electrophoretic mobility shift assay. Nuclear extracts were prepared, and electrophoretic mobility shift assay (EMSA) was performed as described previously (Pahan et al., 2001; Dasgupta et al., 2003a; Auch et al., 2004) with some modifications. Briefly, IRDye infrared dye end-labeled oligonucleotides containing the consensus binding sequence for NF- $\kappa$ B (5'-AGT TGA GGG GAC TTT CCC AGG C-3') were purchased from Licor Biosciences. Six micrograms of nuclear extract was incubated with binding buffer and with infrared-labeled probe for $20 \mathrm{~min}$. Subsequently, samples were separated on a $6 \%$ polyacrylamide gel in $0.25 \times$ TBE buffer (Tris borate-EDTA) and analyzed by the Odyssey Infrared Imaging System (LI-COR Biosciences).

Transmission electron microscopy sample preparation. Aliquots of sample $(5 \mu \mathrm{l})$ were pipetted on to the surface of carbon-coated electron microscope grids and adsorbed for $2 \mathrm{~min}$ at room temperature. After rinsing with $20 \mu \mathrm{l}$ of sterile deionized water, $5 \mu \mathrm{l}$ of $1 \%(\mathrm{w} / \mathrm{v})$ uranyl acetate was added for 15-20 s. Grids were then blotted dry and examined under a JEOL JEM-1220 transmission microscope.

Statistical analysis. All values are expressed as the mean $\pm \mathrm{SD}$ of three independent experiments. Statistical differences between means were calculated by Student's $t$ test. A $p$ value of $<0.05(p<0.05)$ was considered statistically significant.

\section{Results}

Activated primary human astroglia induce apoptosis and cell death in primary human neurons

Recently, glial activation has been attributed to be one of the major causes of neuronal loss in several neurodegenerative disorders, including AD. However, mechanisms by which activated glia facilitate neuronal loss are poorly understood. Because fibrillar $\mathrm{A} \beta_{1-42}$ peptide is an important pathogenic molecule for $\mathrm{AD}$ and astrocytes are major glial cells in the CNS, we examined the effect of $\mathrm{A} \beta_{1-42}$-activated primary human astrocytes on the survival of primary human neurons. To potentiate the neurotoxic effect of $\mathrm{A} \beta$ peptides and to simulate the in vivo situation, astrocytes were stimulated with a combination of fibrillar $\mathrm{A} \beta_{1-42}$ and IL- $1 \beta$. Furthermore, reports from our lab and elsewhere have reported a critical role of IL- $1 \beta$ in the expression of iNOS and the production of $\mathrm{NO}$ in primary human astrocytes either alone or in combination with other neurotoxins (Hua et al., 2002; Jana et al., 2005).

Primary human astrocytes were stimulated with $1 \mu \mathrm{M}$ fibrillar $\mathrm{A} \beta, 10 \mathrm{ng} / \mathrm{ml} \mathrm{IL}-1 \beta$, or a combination of the two for $24 \mathrm{~h}$ under serum-free conditions followed by the addition of activated astrocytes on neurons in a transwell setting, where activated astroglia present on inserts were not in direct contact with neurons cultured on 12-well plates. Under this experimental setting, cytotoxic mediators released from activated astrocytes were able to reach human neurons. After $6 \mathrm{~h}$ of challenge of neurons by activated astrocytes, apoptosis and cell death were analyzed in neurons by terminal deoxynucleotidyl transferase-mediated biotinylated UTP nick end labeling (TUNEL). TdT-mediated labeling of DNA fragments was not observed in control unchallenged neurons (Fig. 1A, top, $C$ ). Unstimulated human astrocytes were also unable to induce any apoptosis in human neurons (Fig. $1 A$, middle, $C$ ). Although either fibrillar $\mathrm{A} \beta$ - or IL- $1 \beta$-activated astrocytes induced some apoptosis in neurons, astrocytes stimulated by the combination of $\mathrm{A} \beta$ and IL- $1 \beta$ were much more potent than either $A \beta$ - or IL- $1 \beta$ - stimulated astrocytes in inducing neuronal apoptosis (Fig. $1 B$, bottom, $D$; supplemental Fig. 1, available at www.jneurosci.org as supplemental material). In another parallel set of experiments, the effect of unstimulated and $\mathrm{A} \beta+\mathrm{IL}-1 \beta$-stimulated astrocytes on neuronal structure was examined after $18 \mathrm{~h}$ of challenge by MAP-2 immunofluorescence. 
Control, unchallenged neurons stained MAP-2 uniformly and exhibited neuronal processes (Fig. $1 C$, top). Unstimulated astrocytes were not able to alter MAP-2 immunoreactivity and neuronal morphology (Fig. $1 C$, middle). On the other hand, we observed loss of neuronal processing and marked decrease in MAP-2 immunoreactivity after challenge by $\mathrm{A} \beta$-stimulated astrocytes (Fig. 1C, bottom).

Activated primary human astroglia induce the activation of N-SMase and the production of ceramide in primary human neurons

Next, to gain insight into molecular mechanisms involved in activated astroglia-induced apoptosis and death of primary human neurons, we explored the role of ceramide, a well-known inducer of apoptosis. Neurons were challenged with $\mathrm{A} \beta+\mathrm{IL}-1 \beta$-activated astrocytes, and the level of ceramide was measured in neurons at different time periods using the DAG kinase assay. Within $30 \mathrm{~min}$ of challenge, activated astroglia were able to induce the level of ceramide by approximately twofold, and with additional increase in duration of insult, the level of ceramide increased markedly (Fig. 1E). After $12 \mathrm{~h}$ of insult, an approximately eightfold increase in ceramide production was recorded in human neurons (Fig. 1E). Because DAG kinase phosphorylates both DAG and ceramide using $\left[\gamma^{-}{ }^{32} \mathrm{P}\right]$ ATP as a substrate, both lipids can be quantified in the same assay. Although the DAG content was much higher than the ceramide content, in contrast to a time-dependent increase in the production of ceramide, the level of DAG in insulted neurons remained almost same at different time points of astroglial insult (data not shown).

Next, to determine whether $\mathrm{A} \beta$-stimulated astroglia induced the production of ceramide in neurons through the activation of SMases, we measured activities of N-SMase and A-SMase in neurons before and after challenge with activated astroglia. As shown in Figure $1 F$, a marked induction of N-SMase activity was observed in primary human neurons in response to activated astrocytes in a transwell setting. Significant increase in N-SMase activity in human neurons was detected as early as 30 min of challenge with activated astrocytes, and the maximum induction ( $\sim 3.5$-fold) was observed at $1 \mathrm{~h}$ of challenge (Fig. $1 F)$. In contrast, $\mathrm{A} \beta$-activated astrocytes were able to increase the activity of A-SMase by $\sim 70 \%$ in neurons (Fig. $1 F$ ) under a similar experimental setting. These results suggest that $\mathrm{A} \beta$-activated human astroglia increase the level of ceramide in human neurons through SMase-mediated catabolism of sphingomyelin.

Activated primary human astroglia induce apoptosis and cell death in primary human neurons via $N$-SMase

Next we examined the role of N-SMase and A-SMase in activated astroglia-mediated neuronal apoptosis. Because ASOs are powerful tools to inhibit target gene expression in nondividing cells in a sequence specific manner, we used ASOs to knock down $\mathrm{N}$-SMase and A-SMase in primary human neurons. As reported in our previous studies (Jana and Pahan, 2004b, a), the following ASOs and $\mathrm{ScOs}$ were used to knock down these molecules: N-SMase, ASO, 5' -CAGCGAGCCCGTCCACCAGCC-3'; ScO, 5' -CACGCGTCCGACGCCGCACGA-3'; A-SMase, ASO, 5' GACATCTCGGAGCCGGGGCA-3'; ScO, 5'-GGAAACCCGGTTAGGCCCGG-3' .

Because these ASOs have become a very critical part of our study, we checked the efficacy of N-SMase and A-SMase ASOs in inhibiting the protein expression of N-SMase and A-SMase by Western blot. As evident from Figure 2A, ASOs against N-SMase
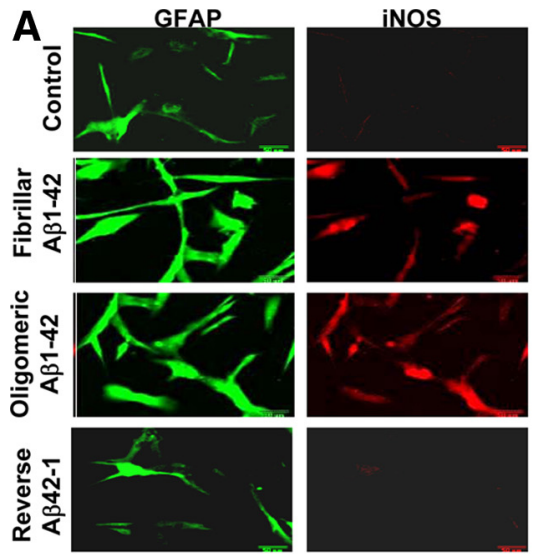

DAPI+Merge
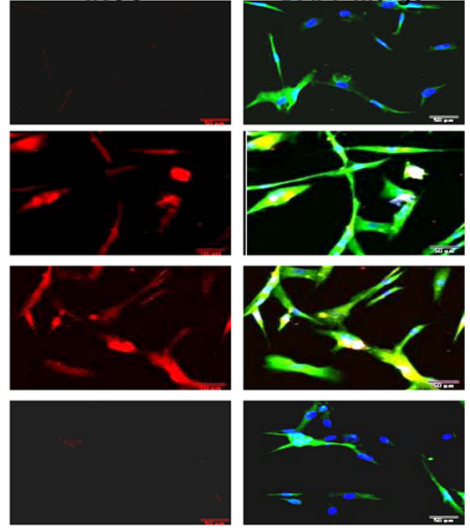

B

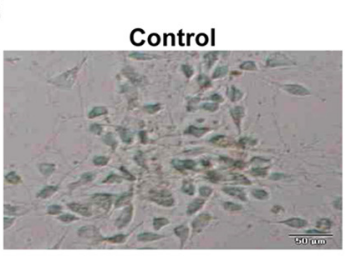

Oligomeric $A \beta$-activated astrocytes (OAA)

ASO + OAA
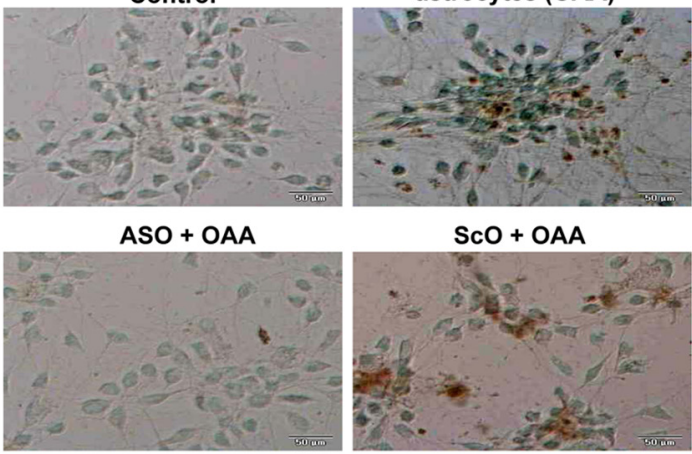

ScO + OAA
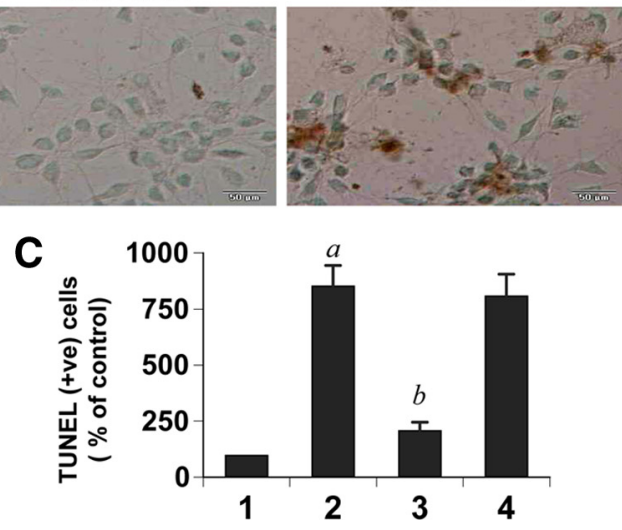

Figure 5. Oligomeric $A \beta_{1-42}$-activated astrocytes induce apoptosis in neurons via N-SMase in neuron-astrocyte transwell cultures. $A$, Primary astrocytes were stimulated with fibrillar $A \beta_{1-42}$, oligomeric $A \beta_{1-42}$, and reverse peptide $A \beta_{42-1}$ for $24 \mathrm{~h}$ followed by double labeling of GFAP and iNOS. $\boldsymbol{B}$, Primary human astrocytes seeded in inserts were stimulated with a combination of $1 \mu \mathrm{m}$ oligomeric $A \beta_{1-42}$ and $10 \mathrm{ng} / \mathrm{ml}$ IL- $1 \beta$ in serum-free media. After $24 \mathrm{~h}$, media were removed and inserts with activated astrocytes were placed on coverslips containing primary neurons that were already pretreated for $40 \mathrm{~h}$ with $1 \mu \mathrm{m}$ ASO or SCO against N-SMase. After $6 \mathrm{~h}$, neuronal apoptosis was monitored by TUNEL. C, TUNEL-positive cells were counted manually in four different images of each of three coverslips by three individuals blinded to the experiment. Values obtained from the control group (1) served as $100 \%$, and data obtained from other three groups, i.e., the oligomeric $A \beta$-activated astrocytes (OAA) group (2), the ASO-OAA group (3), and the SCO-OAA group (4), were calculated as a percentage of control accordingly. Results are the mean \pm SD of three different experiments. ${ }^{a} p<0.001$ versus control; $b<0.001$ versus $0 A$.

effectively inhibited the level of N-SMase, but not A-SMase, protein. Similarly, ASOs against A-SMase suppressed the level of A-SMase, but not N-SMase, protein (Fig. 2 B). On the other hand, $\mathrm{ScOs}$ had no effect on the protein level of either N-SMase or A-SMase (Fig. 2A,B), suggesting the specificity of the effect. Next, we investigated the effect of antisense knockdown of neuronal N-SMase and/or A-SMase on activated glia-induced neuronal apoptosis by TUNEL. As evident from Figure $2 C$, control neurons showed a very few apoptotic bodies after $6 \mathrm{~h}$ of incubation with unstimulated astrocytes in neuron-astrocyte transwell culture, but exhibited a marked increase in apoptosis in response 
to activated astrocytes (Fig. 2C,D). However, ASOs, but not ScOs, against neuronal N-SMase markedly protected neurons from the insult of activated astrocytes (Fig. 2C,D). However, under similar experimental conditions, ASOs against A-SMase failed to rescue neurons (data not shown). To further strengthen these results, we also monitored neuronal death by MTT and LDH. As evidenced by a decrease in MTT metabolism, activated astroglia reduced neuronal viability (Fig. $2 E$ ). Consistent with TUNEL data, ASOs against N-SMase, but not A-SMase, effectively prevented activated astrogliamediated loss of MTT metabolism in human neurons (Fig. 2E). Similarly, treatment of human neurons with ASOs against N-SMase, but not A-SMase, resulted in the significant reduction in $\mathrm{LDH}$ release from neurons (Fig. 2E) in response to insult from activated astrocytes. On the other hand, ScOs against N-SMase showed no effect on cell viability under similar experimental settings (Fig. 2E).

To confirm these results further, we used specific pharmacological inhibitors of N-SMase and A-SMase. Whereas GW4869 is a specific synthetic inhibitor of N-SMase (Luberto et al., 2002), imipramine has been shown to block the activity

of A-SMase, but not N-SMase (Hauck et al., 2000). At first, we checked the specificity of these two inhibitors in our experimental setting. Activated human astrocytes induced the activation of both N-SMase and A-SMase in human neurons (supplemental Fig. 2, available at www.jneurosci.org as supplemental material). Whereas GW4869 strongly suppressed the activity of N-SMase, but not A-SMase, imipramine inhibited the activity of A-SMase, but not N-SMase, in activated astrogliainsulted human neurons (supplemental Fig. 2, available at www. jneurosci.org as supplemental material), suggesting the specificity of these compounds. As evident from MTT metabolism in Figure $2 F$ and LDH release in Figure $2 G$, pretreatment of neurons with GW4869, but not imipramine, was able to protect human neurons from activated astroglia-induced cell death. These findings suggest that $\mathrm{A} \beta$-activated human astrocytes induce apoptosis and cell death in human neurons via N-SMase.

\section{Identification of an astroglial soluble mediator, which is responsible for neuronal death}

In $\mathrm{AD}$, an inflammatory response characterized by glial activation is seen surrounding the plaque region. Results described above clearly suggest that once astroglia become activated, soluble gliotoxins released from these glial cells destroy human neurons via N-SMase. In an effort to identify such an astrogliotoxin that could be responsible for neuronal death, at first we considered the possibility that ceramide was released from activated astrocytes to act intercellularly on neurons as a proapoptotic signal. Primary astrocytes were activated by the combination of $\mathrm{A} \beta$ and IL-1 $\beta$ for different time periods followed by assay of ceramide in conditioned media. As evident from supplemental Figure $3 A$ (available at www.jneurosci.org as supplemental material), we did not notice any increase in extracellular cer- amide. However, as expected, the level of intracellular ceramide increased significantly under the same experimental condition (supplemental Fig. 3B, available at www.jneurosci.org as supplemental material). These results rule out the involvement of extracellular ceramide as a soluble mediator for neuronal death in our transwell culture model. Because activated astroglia also release nitric oxide (NO), a multifunctional molecule, next we investigated any possible role of $\mathrm{NO}$ in neuronal death. Interestingly, pretreatment of neurons with 2-(4-carboxyphenyl)-4,5dihydro-4,4,5,5-tetramethyl-1H-imidazolyl-1-oxy-3-oxide (carboxy-PTIO) (a scavenger of NO) reduced the ability of activated astrocytes to induce the activation of N-SMase (Fig. $3 A$ ), decrease MTT metabolism (Fig. 3B), and increase the release of LDH (Fig. 3C), identifying $\mathrm{NO}$ as a possible astroglial soluble mediator for neuronal death. Although reactive oxygen species are known to activate N-SMase, it was not known whether NO could do the same. We examined whether NO alone was sufficient for the activation of N-SMase in neurons. As evident from Figure 3, diethylenetriamine (DETA)-NONOate, an NO donor, alone markedly induced the activation of N-SMase (Fig. 3D), but not A-SMase (Fig. 3E), in neurons.

Is the activation of human astrocytes dependent on N-SMase? Although soluble gliotoxins released from activated human astrocytes destroy human neurons via N-SMase, it is not known whether N-SMase is also involved during the activation of glial cells. After activation, glial cells release various proinflammatory molecules. Previously we (Jana et al., 2005) found that among various stimuli (lipopolysaccharide, TNF- $\alpha$, IL- $1 \beta$, and interferon- $\gamma$ ) tested, only IL- $1 \beta$ was capable of inducing the production of NO in human fetal astroglia. It is evident from Figure $4 A$ that fibrillar $\mathrm{A} \beta_{1-42}$ alone was also capable of inducing the 
production of $\mathrm{NO}$ in primary human astroglia at a comparable level to that by IL- $1 \beta$. However, the combination of IL- $1 \beta$ and $\mathrm{A} \beta$ induced the production of $\mathrm{NO}$ at a level higher than that found by these stimuli alone (Fig. $4 A$ ). Therefore, we used this combination to stimulate primary human astroglia. Next we investigated the effect of antisense knockdown of N-SMase on the production of NO. It is clear from Figure $4 A$ that antisense knockdown of N-SMase, but not A-SMase, markedly abrogated $\mathrm{A} \beta+\mathrm{IL}-1 \beta$-induced production of $\mathrm{NO}$ in human astroglia. On the other hand, $\mathrm{ScO}$ s had no effect on NO production suggesting the specificity of the effect. Next we examined the effect of chemical knockdown of N-SMase on astroglial production of NO. While GW4869, a specific inhibitor of $\mathrm{N}$-SMase, markedly suppressed A $\beta+$ IL- $1 \beta$-induced production of NO, A-SMase inhibitor imipramine showed no effect on NO production (Fig. $4 B$ ). These results suggest that $\mathrm{N}$-SMase, but not A-SMase, is involved in the production of NO from activated human astroglia.

Next, to confirm these results from another angle; we analyzed the mRNA expression of iNOS in activated astrocytes. As expected, the combination of $A \beta$ and IL- $1 \beta$ induced the expression of iNOS mRNA (Fig. 4C). Consistent with the effect of $\mathrm{N}$-SMase ASOs on the production of $\mathrm{NO}$, antisense knockdown of N-SMase, but not A-SMase, strongly inhibited the expression of iNOS mRNA, whereas ScOs had no impact on A $\beta+\mathrm{IL}-1 \beta$ induced expression of iNOS (Fig. 4C). Real-time PCR data (Fig. $4 D$ ) also corroborated these findings. In addition to expressing iNOS, activated astrocytes are also known to express various proinflammatory cytokines. Consistently, $\mathrm{A} \beta+\mathrm{IL}-1 \beta$ induced the expression of TNF- $\alpha$, IL- $1 \beta$, and IL- 6 mRNAs in human astroglia (Fig. 4E). However, similar to the effect of antisense knockdown of N-SMase on the expression of iNOS mRNA, ASOs against N-SMase, but not A-SMase, abrogated the ability of A $\beta$ plus IL- $1 \beta$ to induce the expression of TNF- $\alpha$, IL- $1 \beta$, and IL- 6 mRNAs (Fig. $4 E$ ). Together, these results suggest that the expression of proinflammatory molecules in activated human astroglia depends on N-SMase but not A-SMase.

\section{Do oligomeric $A \beta_{1-42}$ peptides also activate primary}

human astrocytes?

Although we are using fibrillar $\mathrm{A} \beta$ peptides to mimic activated astroglia-induced neuronal death, recent studies have shown that in addition to fibrillar $\mathrm{A} \beta$, oligomeric $\mathrm{A} \beta$ is also capable of inducing profound inflammatory response in glial cells (White et al., 2005). Therefore, we wondered whether oligomeric $A \beta_{1-42}$ induced the activation of human astroglia and whether oligomeric $\mathrm{A} \beta$-activated astroglia also kill neurons via N-SMase. As expected, fibrillar $\mathrm{A} \beta$ induced the expression of iNOS protein and increased the level of GFAP in human astrocytes (Fig. 5A). Similarly, oligomeric $\mathrm{A} \beta$ also induced iNOS and upregulated GFAP in astrocytes (Fig. 5A). These results are specific, as reverse $\mathrm{A} \beta_{42-1}$ peptides did not have any effect on astroglial GFAP and iNOS (Fig. 5A). Therefore, we next examined the effect of oligomeric $\mathrm{A} \beta$-activated astrocytes on the apoptosis of neurons. Similar to fibrillar $A \beta$-activated astrocytes, oligomeric $A \beta$-activated astrocytes also markedly induced apoptosis of human neurons (Fig. $5 B, C)$, and this effect was blocked by antisense knockdown of $\mathrm{N}$-SMase (Fig. $5 B, C$ ), suggesting that oligomeric $\mathrm{A} \beta$-activated astrocytes also kill neurons via N-SMase.

Does the activation of $N F-\kappa B$ in primary human astrocytes also depend on N-SMase?

Among various transcription factors that are required for the transcription of proinflammatory molecules, NF- $\kappa \mathrm{B}$ is a key
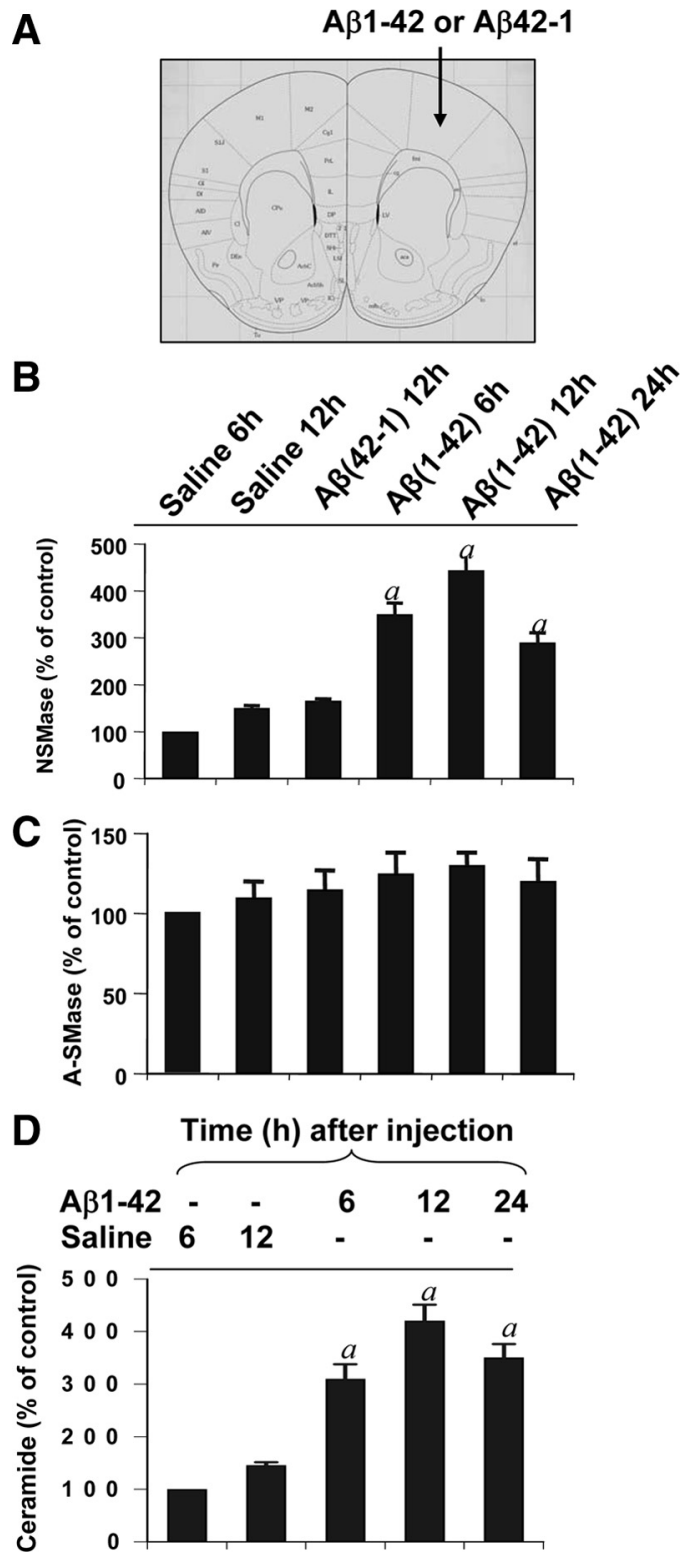

Figure 7. Fibrillar $A \beta_{1-42}$ peptides induce the activation of $N$-SMase and the production of ceramide in vivo in the cortex of $C 57 \mathrm{BL} / 6$ mice. $A$, One microgram of either fibrillar $A \beta_{1-42}$ or reverse $A \beta_{42-1}$ peptides dissolved in saline was stereotaxically injected into the frontal cortex of C57BL/6 mice. Control mice received saline injection. $\boldsymbol{B}-\boldsymbol{D}$, At indicated time points, cortex was dissected out and divided into two halves: one half for measuring activities of N-SMase $(\boldsymbol{B})$ and A-SMase $(\boldsymbol{C})$ and the other for assaying ceramide $(\boldsymbol{D})$. The control (saline, $6 \mathrm{~h}$ ) group served as $100 \%$, and data from other groups were expressed as a percentage of control. Results are the mean \pm SD of five different mice $(n=5) .{ }^{a} p<0.05$ versus saline $(6 \mathrm{~h})$.

transcription factor involved in the transcription of almost all proinflammatory molecules (Blackwell and Christman, 1997). Therefore, to understand the basis of suppression of proinflammatory molecules by inhibition of N-SMase, we examined whether the activation of NF- $\kappa \mathrm{B}$ in $\mathrm{A} \beta$-stimulated astroglia was also regulated by N-SMase. Activation of NF- $\kappa \mathrm{B}$ was monitored by DNA binding activity of NF- $\kappa$ B (Pahan et al., 2000b; Brahmachari et al., 2006). DNA binding activity of NF- $\kappa$ B was evaluated by the formation of a distinct and specific complex in a gel shift DNA binding assay. Treatment of primary human astroglia with $\mathrm{A} \beta+\mathrm{IL}-1 \beta$ resulted in the induction of DNA binding activity of NF- $\kappa \mathrm{B}$ (Fig. $6 A$ ). This gel shift assay detected a specific band in 

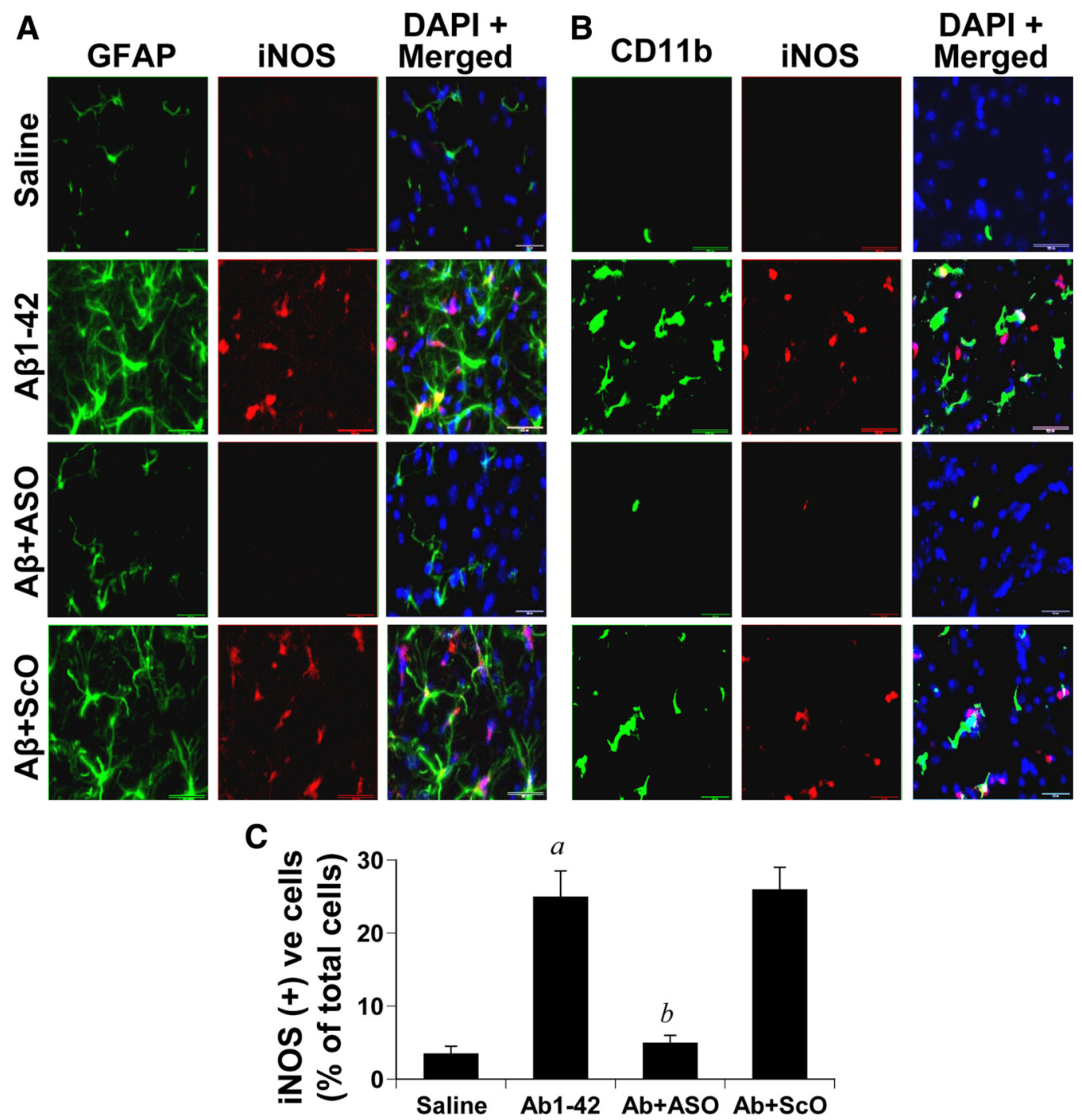

Figure 8. Antisense knockdown of N-SMase attenuates the activation of astrog lia and microglia and reduces the expression of iNOS in vivo in the cortex of C57BL/6 mice. One microgram of either $\mathrm{ASO}$ or Sc 0 against N-SMase dissolved in $2 \mu \mathrm{l}$ of saline was stereotaxically injected into the frontal cortex of $\mathrm{C} 57 \mathrm{BL} / 6$ mice. After $24 \mathrm{~h}$ of microinjection, $1 \mu \mathrm{g}$ of fibrillar $\mathrm{A} \beta_{1-42}$ in a $2 \mu \mathrm{l}$ volume was again microinjected at the same site. $\boldsymbol{A}, \boldsymbol{B}$, After $6 \mathrm{~h}$ of $\mathrm{A} \beta$ microinjection, mice were perfused, and double immunofluorescence for GFAP (green) and iNOS (red) (A) and CD11b (green) and iNOS (red) $(\boldsymbol{B})$ was performed. Five mice $(n=5)$ were used in each group. C, Cells positive for iNOS as well as total $4^{\prime}, 6^{\prime}$-diamidino-2-phenylindole-positive cells were counted in three cortical sections (two images per slide) of each of five different mice with an Olympus IX81 fluorescence microscope using the MicroSuite imaging software. Results are expressed as the number of iNOS-positive cells per 100 cells. ${ }^{a} p<0.001$ versus saline; ${ }^{b} p<0.001$ versus $A \beta$.

response to $\mathrm{A} \beta+\mathrm{IL}-1 \beta$ (Fig. 6) that was competed off by an unlabeled probe (data not shown), suggesting that $A \beta+\mathrm{IL}-1 \beta$ induces the DNA-binding activity of NF- $\kappa$ B. However, ASOs against N-SMase, but not A-SMase, suppressed A $\beta+$ IL- $1 \beta$ induced DNA-binding activity of NF- $\kappa \mathrm{B}$ (Fig. $6 A$ ). On the other hand, under similar condition, ScOs had no effect on the DNAbinding activity of NF- $\kappa \mathrm{B}$ (Fig. $6 A$ ). To confirm these results further, we used chemical inhibitors of N-SMase and A-SMase. Consistent to antisense results, N-SMase inhibitor GW4869, but not A-SMase inhibitor imipramine, markedly suppressed A $\beta+\mathrm{IL}-1 \beta$ induced DNA-binding activity of NF- $\kappa \mathrm{B}$ (Fig. $6 B, C$ ). These results clearly indicate that the activation of NF- $\kappa \mathrm{B}$ in human astrocytes also depends on N-SMase, but not A-SMase.

Fibrillar $A \beta_{1-42}$ peptides induce the activation of $N$-SMase and the production of ceramide in vivo in the cortex of male C57BL/6 mice Using various approaches, the studies presented above demonstrate that fibrillar $\mathrm{A} \beta$-activated astroglia kill neurons via
$\mathrm{N}$-SMase and that fibrillar $\mathrm{A} \beta$ also activates astroglia via $\mathrm{N}$-SMase. Next, to address whether these findings could be reproduced in vivo in the cortex of mice, fibrillar $\mathrm{A} \beta_{1-42}$ peptides were microinjected into the cortex of male C57BL/6 mice (10-12 weeks old) (Fig. 7A). First, we examined whether $\mathrm{A} \beta$ peptides were able to induce the activation of N-SMase and the production of ceramide in vivo in the cortex. As evident from Figure $7 B$, microinjection of $A \beta_{1-42}$ peptides led to marked increase in the activation of N-SMase compared to saline microinjection. A more than threefold increase in the activity of N-SMase was observed at $6 \mathrm{~h}$ of microinjection and it increased further at $12 \mathrm{~h}$ (Fig. $7 B$ ). However, activity of N-SMase decreased at $24 \mathrm{~h}$ of microinjection (Fig. $7 B$ ). In contrast, reverse peptides $\left(\mathrm{A} \beta_{42-1}\right)$ were unable to increase the activity of N-SMase in vivo in the cortex compared to saline microinjection (Fig. $7 B$ ). Whereas after $12 \mathrm{~h}$ of microinjection, $\mathrm{A} \beta_{1-42}$ increased the activity of $\mathrm{N}$-SMase by $>300 \%$ compared to saline, $\mathrm{A} \beta_{42-1}$ remained unable 

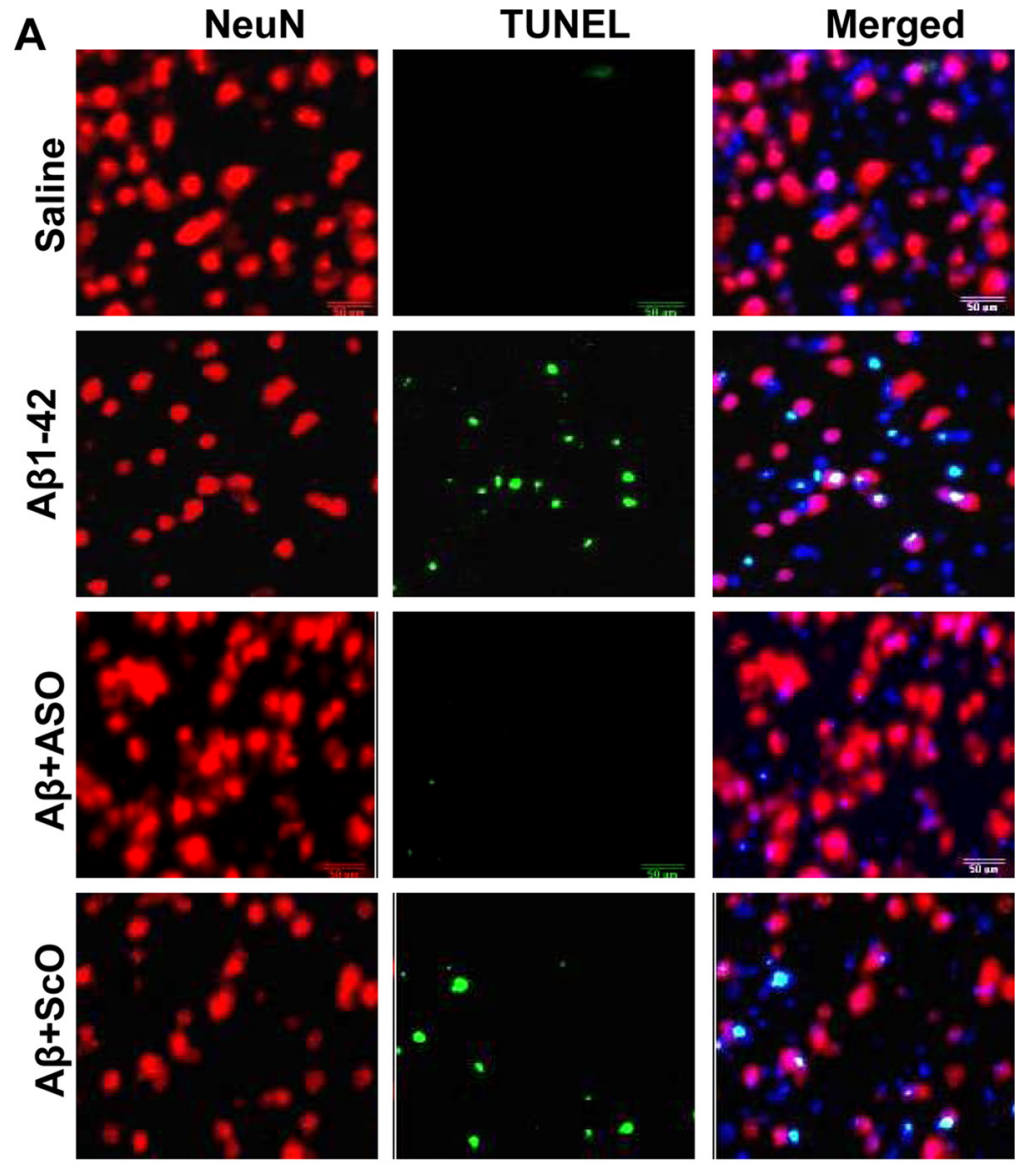

B

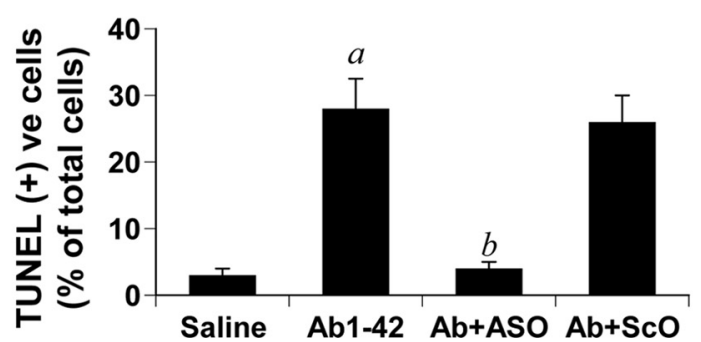

Figure 9. Antisense oligonucleotides against N-SMase protect neurons from fibrillar A $\beta$ toxicity in vivo in the cortex of $C 57 \mathrm{BL} / 6$ mice. One microgram of either ASO or ScO against N-SMase dissolved in $2 \mu \mathrm{l}$ of saline was stereotaxically injected into the frontal cortex. After $24 \mathrm{~h}$ of microinjection, $1 \mu \mathrm{g}$ of fibrillar $A \beta_{1-42}$ in a $2 \mu$ l volume was again microinjected at the same site. $A, A f t e r 24 \mathrm{~h}$ of the final microinjection, mice were perfused and double immunofluorescence for NeuN (red), and TUNEL (green) was performed. Five mice ( $n=5$ ) were used in each group. $\boldsymbol{B}$, TUNEL-positive cells as well as total $4^{\prime}, 6^{\prime}$-diamidino-2-phenylindole-positive cells were counted in three cortical sections ( 2 images per slide) of each of five different mice with an 0lympus IX81 fluorescence microscope using the MicroSuite imaging software. Results are expressed as the number of TUNEL-positive cells per 100 cells. ${ }^{a} p<$ 0.001 versus saline; ${ }^{b} p<0.001$ versus $A \beta$.

to increase its activity significantly at the same time point (Fig. $7 B)$. However, under same experimental setting, microinjection of saline, $\mathrm{A} \beta_{1-42}$, or $\mathrm{A} \beta_{42-1}$ was unable to increase the activity of A-SMase significantly in the cortex (Fig. $7 C$ ). Then, we monitored the level of ceramide in the cortex. Fibrillar $A \beta_{1-42}$ peptides caused an approximately threefold increase in the ceramide level after $6 \mathrm{~h}$ and an approximately fourfold increase in the ceramide level after $12 \mathrm{~h}$, compared to an $\sim 30 \%$ increase in ceramide level in salinemicroinjected cortex at $6 \mathrm{~h}$ (Fig. $7 D$ ). Together, these findings suggest that fibrillar $A \beta_{1-42}$ peptides induce the generation of ceramide in vivo in the cortex and that ceramide production is attributable to the activation of N-SMase, but not A-SMase.
Does antisense knockdown of N-SMase inhibit fibrillar $A \beta$-mediated astrogliosis in vivo in the cortex of $C 57 B L / 6$ mice?

At first, we examined efficacy and specificity of ASOs against mouse N-SMase ( $\mathrm{mN}$-SMase) in vivo in the cortex. Sequences of ASOs and $\mathrm{ScOs}$ against $\mathrm{mN}$ SMase were as follows: ASO, 5'-CAG CGA GCC GGT CCA CCA GCC-3' ; ScO, 5'-CAC GCG TCC GAC GCC GCA CGA- $3^{\prime}$.

It is clearly evident from supplemental Figure $4 A$ (available at www.jneurosci.org as supplemental material) that fibrillar $\mathrm{A} \beta_{1-42}$ increased the activity of N-SMase in vivo in the cortex by more than fourfold compared to saline. However, premicroinjection of $\mathrm{mN}$-SMase ASOs, but not ScOs, was capable of suppressing $\mathrm{A} \beta_{1-}$ 42-induced activation of N-SMase in vivo in the cortex (supplemental Fig. $4 \mathrm{~A}$, available at www.jneurosci.org as supplemental material). We also observed an $~ 35 \%$ increase in the activity of A-SMase after A $\beta$ microinjection (supplemental Fig. $4 B$, available at www.jneurosci.org as supplemental material). However, either $\mathrm{mN}$ SMase ASOs or mN-SMase ScOs did not influence the activity of A-SMase in fibrillar $A \beta$-microinjected cortex (supplemental Fig. $4 B$, available at www.jneurosci.org as supplemental material).

Glial activation and neuronal apoptosis are two hallmarks of $\mathrm{AD}$. We investigated whether fibrillar $\mathrm{A} \beta_{1-42}$ peptides were capable of inducing glial activation and neuronal apoptosis in vivo in the cortex. To understand whether both are occurring simultaneously or the one is preceding the other in fibrillar $\mathrm{A} \beta_{1-42^{-}}$ insulted cortex, we analyzed glial expression of iNOS and neuronal TUNEL bodies in cortical sections after 6 and $24 \mathrm{~h}$ of microinjection. Astroglia are the major cell type in the brain and increase in GFAP expression represents an important way to monitor astroglial activation (Brahmachari et al., 2006). After activation, astrocytes express iNOS and produce $\mathrm{NO}$, and we demonstrated previously that NO plays a critical role in the upregulation of GFAP in astroglia (Brahmachari et al., 2006). Similarly, activated microglia also express considerable amount of iNOS, and we have demonstrated that NO is an important factor in increasing microglial surface markers required for gliosis (Roy et al., 2006). Therefore, we monitored the expression of iNOS in both GFAP- and CD11b-positive cells in cortical sections. Fibrillar $\mathrm{A} \beta_{1-42}$ peptides induced the expression of iNOS in GFAP-positive astrocytes and CD11b-positive microglia within $6 \mathrm{~h}$ of microinjection (data not shown). However, fibrillar $\mathrm{A} \beta$ peptides were unable to induce any apoptosis in neurons (NeuN-positive cells) within this time period (data not shown). On the other hand, at $24 \mathrm{~h}$ of microinjection, both 
glial expression of iNOS and neuronal apoptosis were observed (data not shown). These results clearly suggest that in the $\mathrm{A} \beta$-microinjected model, glial activation is followed by neuronal apoptosis.

Therefore, first we investigated the effect of N-SMase ASO on glial activation. As evident from Figure $8 A$, the level of iNOS was almost undetectable, and the level of GFAP was also very low in salinemicroinjected mice. On the other hand, marked increase in the expression of iNOS and GFAP was observed in $A \beta$ injected mice, and many iNOS signals colocalized with GFAP-positive astroglia after both $6 \mathrm{~h}$ (Fig. $8 \mathrm{~A}$ ) and $24 \mathrm{~h}$ (data not shown) of microinjection. Similarly, $A \beta$ microinjection also induced microglial activation as evidenced from increased iNOS staining in CD11b-positive microglia after $6 \mathrm{~h}$ (Fig. $8 \mathrm{~A}$ ) and $24 \mathrm{~h}$ (data not shown) of microinjection. However, antisense knockdown of N-SMase dramatically reduced the expression of iNOS, GFAP, and CD11b in vivo in the cortex of $\mathrm{A} \beta$-microinjected mice at both 6 and $24 \mathrm{~h}$ of microinjection. On the other hand, as expected, $\mathrm{N}$-SMase $\mathrm{ScO}$ s had no effect on the expression of iNOS, GFAP, and CD11b (Fig. 8). Because there was no neuronal apoptosis in vivo in the cortex after $6 \mathrm{~h}$ of microinjection, our results clearly suggest that knockdown of N-SMase is capable of abrogating the inflammatory response in glial cells without involving neuronal apoptosis.

\section{Antisense knockdown of $N$-SMase protects neurons from $A \beta$} toxicity in vivo in the cortex of C57BL/6 mice

Next we investigated whether fibrillar $\mathrm{A} \beta_{1-42}$ peptides induced neuronal apoptosis in vivo in the cortex. Cortical sections were double labeled for TUNEL and NeuN. As evident from Figure 9, fibrillar $\mathrm{A} \beta_{1-42}$ markedly induced the apoptotic death of neurons in vivo in the cortex as evidenced by the increase in TUNEL signal in NeuN-positive cells. We wondered whether fibrillar $\mathrm{A} \beta$ also induced apoptosis in the other three cell types in the cortex. In contrast to marked apoptosis of neurons, we did not observe any apoptosis in either GFAP-positive astroglia or Iba1-positive microglia (data not shown). However, TUNEL bodies colocalized with O4-positive oligodendroglia and oligodendroglial progenitors (data not shown). This is consistent with the finding of Lee et al. (2004) that $\mathrm{A} \beta$ peptides induce oligodendroglial apoptosis. Next we investigated whether antisense knockdown of $\mathrm{mN}$ SMase was capable of protecting neurons in vivo in the cortex from $\mathrm{A} \beta$ toxicity. As evident from Figure $9, A$ and $B$, the increase in the apoptotic death in vivo in the cortex was blocked by $\mathrm{mN}$-SMase ASOs. On the other hand, $\mathrm{mN}$-SMase ScOs did not ameliorate cell death in $\mathrm{A} \beta$ injected mice under similar experimental conditions, suggesting the specificity of the protective effect (Fig. 9).

\section{Discussion}

Although the disease mechanisms that cause AD are poorly understood, recent studies strongly support the role of inflammation in neurodegeneration in this disease (MacKenzie, 1996;
Akiyama et al., 2000; McGeer and McGeer, 2001; Walsh and Aisen, 2004; Heneka and O'Banion, 2007; Rogers, 2008; Rezai-Zadeh et al., 2009). First, early intervention with nonsteroidal antiinflammatory drugs slows disease incidence (in t' Veld et al., 2001; Szekely et al., 2004, 2007). Second, significant astroglial and microglial activation occurs in close proximity to neuritic plaques containing $A \beta$. Third, overexpression of astrocytic S100B leads to brain inflammation and exacerbation of Alzheimer's disease pathology in a mouse model of the disease (Mori et al. 2010). Fourth, the concentration of $\mathrm{NO}_{2}$ - (nitrite), a metabolite of NO, increases in the CSF of patients with AD compared to age-matched controls (Luth and Arendt, 1998; Tohgi et al., 1999). It has been shown that glial cells in the cortex from postmortem AD samples express considerable amounts of inducible iNOS, whereas those from age-matched controls do not (Luth et al., 2002; Fernandez-Vizarra et al., 2004) Fifth, a variety of proinflammatory cytokines including TNF- $\alpha$, IL- $1 \beta$, IL-6, eicosanoids, and other immune neurotoxins are found in either CSF or affected brain regions in $\mathrm{AD}$ (Sun et al., 2003; Tarkowski et al., 2003; Cacquevel et al., 2004). Sixth, concentrations of various chemokines, such as IL-8, monocyte chemoattractant protein-1, and interferon gamma-induced protein-10 increase in CSF of patients with mild cognitive impairment and $\mathrm{AD}$ compared to age-matched control (Sun et al., 2003; Galimberti et al., 2006). Seventh, NF- $\kappa \mathrm{B}$ is considered as a proinflammatory transcription factor because of its involvement in the transcription of almost all proinflammatory molecules (Muller-Ladner et al., 2002). It has been found that in AD brains, NF- $\kappa B$ immunoreactivity is higher in astrocytes surrounding the plaque region. Eighth, in addition to releasing nitric oxide, proinflammatory cytokines, and chemokines, activated glia also produce reactive oxygen species and eicosanoids capable of damaging neurons. Together, 
these studies demonstrate the utmost importance of unraveling mechanisms of glial activation and activated glia-mediated neuronal death for providing significant insight into the pathophysiology of $\mathrm{AD}$ and developing treatment paradigms.

Intracellular signaling mechanisms involved in $\mathrm{A} \beta$-induced glial activation are poorly understood. Recent studies have shown that $\mathrm{A} \beta$ activates three subtypes of mitogen-activated protein kinases (MAPKs) in glial cells, such as extracellular signalregulated kinase (ERK), c-Jun N-terminal kinase (JNK), and p38 kinase (Bodles and Barger, 2005). Out of the three MAPKs, p38 and JNK, but not ERK1/2, have been shown to play important roles in mediating the activation of glia (Xie et al., 2004; Bodles and Barger, 2005). Here we have found that fibrillar $A \beta_{1-42}$ peptides activate human astroglia via neutral sphingomyelinase $(\mathrm{N}$ SMase). First, knockdown of N-SMase by either chemical inhibitor or antisense oligonucleotides suppresses $\mathrm{A} \beta$-induced production of nitrite and the expression of iNOS and proinflammatory cytokines (TNF- $\alpha$, IL- $1 \beta$, and IL- 6 ) in primary human astrocytes. On the other hand, knockdown of A-SMase had no effect on $\mathrm{A} \beta$-induced activation of human astroglia, suggesting the specificity of the effect. Previous studies have also shown the involvement of N-SMase in the induction and/or stimulation of iNOS in C6 rat glioma cells (Won et al., 2004) or oligodendrocytes (Zeng et al., 2005). Second, inhibition of N-SMase, but not A-SMase, attenuated the activation of NF- $\kappa \mathrm{B}$ in fibrillar $\mathrm{A} \beta-$ stimulated human astrocytes. Our result is in direct contrast with previous reports where TNF- $\alpha$ has been shown to induce the activation of NF- $\kappa$ B via A-SMase (Van Antwerp et al., 1996; Wang et al., 1996). Whereas TNF- $\alpha$ requires the TNF receptor $1-\mathrm{A}-\mathrm{SMase}$ pathway for the activation of NF- $\kappa \mathrm{B}$, fibrillar $\mathrm{A} \beta$ couples different receptors (receptor for advanced glycation end products, scavenger receptor, etc.), which may prefer N-SMase for transducing signals for the activation of NF- $\kappa \mathrm{B}$ in human astroglia. Third, antisense knockdown of N-SMase also inhibited the expression of iNOS in vivo in fibrillar $\mathrm{A} \beta$-intoxicated mouse cortex. We demonstrated previously that fibrillar $\mathrm{A} \beta$ kills human neurons via activation of N-SMase (Jana and Pahan, 2004b). Here we demonstrate that fibrillar $\mathrm{A} \beta$ activates human astroglia in culture and mouse astroglia in vivo in the cortex via N-SMase. Previously, Pahan et al. (1998) showed that ceramide stimulates the activation of NF- $\kappa \mathrm{B}$ and the expression of iNOS in primary rat astrocytes. Recently, we demonstrated that NO is an important signal for the upregulation of GFAP in astrocytes. Therefore, it appears that the activation of N-SMase-ceramide pathway is one of the earlier events for the initiation of NF- $\kappa \mathrm{B}-\mathrm{iNOS}-\mathrm{NO}-$ GFAP pathway, which ultimately culminates into astroglial activation and astrogliosis. Here we have also delineated a nice feedback regulation of N-SMase by $\mathrm{NO}$ as well. Although proinflammatory cytokines (TNF- $\alpha$ and IL-1 $\beta$ ) and reactive oxygen species are known to induce $\mathrm{N}$-SMase, it was not known whether $\mathrm{NO}$ is capable of activating N-SMase. Our results suggest that NO produced from activated glial cells could activate N-SMase on its own in neurons.

Once glial cells are activated, in addition to producing $\mathrm{NO}$, these activated cells produce diverse set of molecules, such as proinflammatory cytokines, proinflammatory chemokines, reactive oxygen species, and arachidonic acid, which could damage neurons on their own. Therefore, it is important to identify a common molecule where various signaling pathways emanating from different neurotoxic molecules converge. Several lines of evidence presented in this manuscript clearly indicate that $\mathrm{A} \beta$ activated primary human astroglia kill primary human neurons via $\mathrm{N}$-SMase. First, in a transwell setting where astrocytes were not in direct contact with neurons, fibrillar $\mathrm{A} \beta$-activated astroglia induced the activation of N-SMase, the production of ceramide, and cell death in neurons. However, antisense knockdown of neuronal N-SMase, but not A-SMase, protected these cells against fibrillar $\mathrm{A} \beta$-activated astroglia as evidenced by decrease in TUNEL-positive cells, amelioration in LDH release, and restoration of MTT metabolism. Consistently, treatment of neurons with N-SMase inhibitor GW4869, but not A-SMase inhibitor imipramine, also led to protection of neurons from activated astroglia insult. Second, stereotaxic injection of fibrillar $A \beta_{1-42}$ peptides, but not soluble $\mathrm{A} \beta_{42-1}$ reverse peptides, increased the activity of N-SMase, the production of ceramide, and the apoptosis of neurons in mouse cortex. However, antisense knockdown of N-SMase protected cholinergic neurons in vivo in the cortex from fibrillar $\mathrm{A} \beta$ toxicity.

In vivo in the brain of $\mathrm{AD}$ patients, fibrillar $\mathrm{A} \beta$ peptides exert effect on neurons as well as glial cells. Although according to our earlier work (Jana and Pahan, 2004b) knockdown of N-SMase protects neurons from direct toxic effects of fibrillar $A \beta$, glialderived neurotoxic factors may kill neurons independent of $\mathrm{N}$-SMase, thereby limiting the therapeutic potential of inhibitors of N-SMase in AD. Therefore, we performed this study. Here we demonstrate that fibrillar $\mathrm{A} \beta$ activates glial cells via $\mathrm{N}$-SMase and that N-SMase is also involved in activated glial cell-induced neuronal death (Fig. 10). These results suggest that N-SMase is the converging point of multiple neurotoxic signaling pathways (Fig. 10). Although the in vitro situation of human fetal neurons and astroglia in culture does not truly resemble the in vivo situation of neurons in the brain of $\mathrm{AD}$ patients, our results suggest that specific targeting of N-SMase may be an important therapeutic avenue to halt neuronal damage in $\mathrm{AD}$ and other neurodegenerative disorders.

\section{References}

Akiyama H, Barger S, Barnum S, Bradt B, Bauer J, Cole GM, Cooper NR, Eikelenboom P, Emmerling M, Fiebich BL, Finch CE, Frautschy S, Griffin WS, Hampel H, Hull M, Landreth G, Lue L, Mrak R, Mackenzie IR, McGeer PL, et al. (2000) Inflammation and Alzheimer's disease. Neurobiol Aging 21:383-421.

Auch CJ, Saha RN, Sheikh FG, Liu X, Jacobs BL, Pahan K (2004) Role of protein kinase $\mathrm{R}$ in double-stranded RNA-induced expression of nitric oxide synthase in human astroglia. FEBS Lett 563:223-228.

Blackwell TS, Christman JW (1997) The role of nuclear factor-kappa B in cytokine gene regulation. Am J Respir Cell Mol Biol 17:3-9.

Bodles AM, Barger SW (2005) Secreted beta-amyloid precursor protein activates microglia via JNK and p38-MAPK. Neurobiol Aging 26:9-16.

Braak H, Braak E, Strothjohann M (1994) Abnormally phosphorylated tau protein related to the formation of neurofibrillary tangles and neuropil threads in the cerebral cortex of sheep and goat. Neurosci Lett 171:1-4.

Brahmachari S, Fung YK, Pahan K (2006) Induction of glial fibrillary acidic protein expression in astrocytes by nitric oxide. J Neurosci 26:4930-4939.

Brugg B, Michel PP, Agid Y, Ruberg M (1996) Ceramide induces apoptosis in cultured mesencephalic neurons. J Neurochem 66:733-739.

Cacquevel M, Lebeurrier N, Cheenne S, Vivien D (2004) Cytokines in neuroinflammation and Alzheimer's disease. Curr Drug Targets 5:529-534.

Dasgupta S, Jana M, Liu X, Pahan K (2003a) Role of very-late antigen-4 (VLA-4) in myelin basic protein-primed T cell contact-induced expression of proinflammatory cytokines in microglial cells. J Biol Chem 278:22424-22431.

Dasgupta S, Zhou Y, Jana M, Banik NL, Pahan K (2003b) Sodium phenylacetate inhibits adoptive transfer of experimental allergic encephalomyelitis in SJL/J mice at multiple steps. J Immunol 170:3874-3882.

Dasgupta S, Jana M, Zhou Y, Fung YK, Ghosh S, Pahan K (2004) Antineuroinflammatory effect of NF-kappaB essential modifier-binding domain peptides in the adoptive transfer model of experimental allergic encephalomyelitis. J Immunol 173:1344-1354.

Fernandez-Vizarra P, Fernandez AP, Castro-Blanco S, Encinas JM, Serrano J, Bentura ML, Munoz P, Martinez-Murillo R, Rodrigo J (2004) Expres- 
sion of nitric oxide system in clinically evaluated cases of Alzheimer's disease. Neurobiol Dis 15:287-305.

Galimberti D, Schoonenboom N, Scheltens P, Fenoglio C, Venturelli E, Pijnenburg YA, Bresolin N, Scarpini E (2006) Intrathecal chemokine levels in Alzheimer disease and frontotemporal lobar degeneration. Neurology 66:146-147.

Giovannini MG, Scali C, Prosperi C, Bellucci A, Vannucchi MG, Rosi S, Pepeu G, Casamenti F (2002) Beta-amyloid-induced inflammation and cholinergic hypofunction in the rat brain in vivo: involvement of the p38MAPK pathway. Neurobiol Dis 11:257-274.

Hannun YA (1996) Functions of ceramide in coordinating cellular responses to stress. Science 274:1855-1859.

Hauck CR, Grassme H, Bock J, Jendrossek V, Ferlinz K, Meyer TF, Gulbins E (2000) Acid sphingomyelinase is involved in CEACAM receptormediated phagocytosis of Neisseria gonorrhoeae. FEBS Lett 478:260-266.

Heneka MT, O'Banion MK (2007) Inflammatory processes in Alzheimer's disease. J Neuroimmunol 184:69-91.

Hsiao K, Chapman P, Nilsen S, Eckman C, Harigaya Y, Younkin S, Yang F, Cole G (1996) Correlative memory deficits, Abeta elevation, and amyloid plaques in transgenic mice. Science 274:99-102.

Hua LL, Zhao ML, Cosenza M, Kim MO, Huang H, Tanowitz HB, Brosnan CF, Lee SC (2002) Role of mitogen-activated protein kinases in inducible nitric oxide synthase and TNFalpha expression in human fetal astrocytes. J Neuroimmunol 126:180-189.

in t' Veld BA, Ruitenberg A, Hofman A, Launer LJ, van Duijn CM, Stijnen T, Breteler MM, Stricker BH (2001) Nonsteroidal antiinflammatory drugs and the risk of Alzheimer's disease. N Engl J Med 345:1515-1521.

Jana A, Pahan K (2004a) Human immunodeficiency virus type 1 gp120 induces apoptosis in human primary neurons through redox-regulated activation of neutral sphingomyelinase. J Neurosci 24:9531-9540.

Jana A, Pahan K (2004b) Fibrillar amyloid-beta peptides kill human primary neurons via NADPH oxidase-mediated activation of neutral sphingomyelinase. Implications for Alzheimer's disease. J Biol Chem 279: 51451-51459.

Jana A, Pahan K (2007) Oxidative stress kills human primary oligodendrocytes via neutral sphingomyelinase: implications for multiple sclerosis. J Neuroimmune Pharmacol 2:184-193.

Jana M, Pahan K (2005) Redox regulation of cytokine-mediated inhibition of myelin gene expression in human primary oligodendrocytes. Free Radic Biol Med 39:823-831.

Jana M, Liu X, Koka S, Ghosh S, Petro TM, Pahan K (2001) Ligation of CD40 stimulates the induction of nitric-oxide synthase in microglial cells. J Biol Chem 276:44527-44533.

Jana M, Anderson JA, Saha RN, Liu X, Pahan K (2005) Regulation of inducible nitric oxide synthase in proinflammatory cytokine-stimulated human primary astrocytes. Free Radic Biol Med 38:655-664.

Jana M, Jana A, Pal U, Pahan K (2007) A simplified method for isolating highly purified neurons, oligodendrocytes, astrocytes, and microglia from the same human fetal brain tissue. Neurochem Res 32:2015-2022.

Jantaratnotai N, Ryu JK, Kim SU, McLarnon JG (2003) Amyloid beta peptide-induced corpus callosum damage and glial activation in vivo. NeuroReport 14:1429-1433.

Keane RW, Srinivasan A, Foster LM, Testa MP, Ord T, Nonner D, Wang HG, Reed JC, Bredesen DE, Kayalar C (1997) Activation of CPP32 during apoptosis of neurons and astrocytes. J Neurosci Res 48:168-180.

Lee JT, Xu J, Lee JM, Ku G, Han X, Yang DI, Chen S, Hsu CY (2004) Amyloid-beta peptide induces oligodendrocyte death by activating the neutral sphingomyelinase-ceramide pathway. J Cell Biol 164:123-131.

Liu X, Jana M, Dasgupta S, Koka S, He J, Wood C, Pahan K (2002) Human immunodeficiency virus type 1 (HIV-1) tat induces nitric-oxide synthase in human astroglia. J Biol Chem 277:39312-39319.

Luberto C, Hassler DF, Signorelli P, Okamoto Y, Sawai H, Boros E, HazenMartin DJ, Obeid LM, Hannun YA, Smith GK (2002) Inhibition of tumor necrosis factor-induced cell death in MCF7 by a novel inhibitor of neutral sphingomyelinase. J Biol Chem 277:41128-41139.

Luth HJ, Arendt T (1998) Nitric oxide and Alzheimer's disease. J fur Hirnforschung 39:245-251.

Luth HJ, Munch G, Arendt T (2002) Aberrant expression of NOS isoforms in Alzheimer's disease is structurally related to nitrotyrosine formation. Brain Res 953:135-143.

MacKenzie IR (1996) Antiinflammatory drugs in the treatment of Alzheimer's disease. J Rheumatol 23:806-808.
Martin JB (1999) Molecular basis of the neurodegenerative disorders. N Engl J Med 340:1970-1980.

McGeer EG, McGeer PL (2001) Innate immunity in Alzheimer's disease: a model for local inflammatory reactions. Mol Interv 1:22-29.

Meda L, Cassatella MA, Szendrei GI, Otvos L Jr, Baron P, Villalba M, Ferrari D, Rossi F (1995) Activation of microglial cells by beta-amyloid protein and interferon-gamma. Nature 374:647-650.

Mori T, Koyama N, Arendash GW, Horikoshi-Sakuraba Y, Tan J, Town T (2010) Overexpression of human S100B exacerbates cerebral amyloidosis and gliosis in the Tg2576 mouse model of Alzheimer's disease. Glia 58:300-314.

Muller-Ladner U, Gay RE, Gay S (2002) Role of nuclear factor kappaB in synovial inflammation. Curr Rheumatol Rep 4:201-207.

Nichols NR (1999) Glial responses to steroids as markers of brain aging. J Neurobiol 40:585-601.

Pahan K, Sheikh FG, Khan M, Namboodiri AM, Singh I (1998) Sphingomyelinase and ceramide stimulate the expression of inducible nitric-oxide synthase in rat primary astrocytes. J Biol Chem 273:2591-2600.

Pahan K, Khan M, Singh I (2000a) Interleukin-10 and interleukin-13 inhibit proinflammatory cytokine-induced ceramide production through the activation of phosphatidylinositol 3-kinase. J Neurochem 75:576-582.

Pahan K, Liu X, McKinney MJ, Wood C, Sheikh FG, Raymond JR (2000b) Expression of a dominant-negative mutant of $\mathrm{p} 21$ (ras) inhibits induction of nitric oxide synthase and activation of nuclear factor-kappaB in primary astrocytes. J Neurochem 74:2288-2295.

Pahan K, Sheikh FG, Liu X, Hilger S, McKinney M, Petro TM (2001) Induction of nitric-oxide synthase and activation of NF-kappaB by interleukin-12 p40 in microglial cells. J Biol Chem 276:7899-7905.

Pettus BJ, Chalfant CE, Hannun YA (2002) Ceramide in apoptosis: an overview and current perspectives. Biochim Biophys Acta 1585:114-125.

Pike CJ, Burdick D, Walencewicz AJ, Glabe CG, Cotman CW (1993) Neurodegeneration induced by beta-amyloid peptides in vitro: the role of peptide assembly state. J Neurosci 13:1676-1687.

Rezai-Zadeh K, Gate D, Town T (2009) CNS infiltration of peripheral immune cells: D-Day for neurodegenerative disease? J Neuroimmune Pharmacol 4:462-475.

Rogers J (2008) The inflammatory response in Alzheimer's disease. J Periodontol 79:1535-1543.

Roy A, Fung YK, Liu X, Pahan K (2006) Up-regulation of microglial CD11b expression by nitric oxide. J Biol Chem 281:14971-14980.

Saha RN, Jana M, Pahan K (2007) MAPK p38 regulates transcriptional activity of NF-kappaB in primary human astrocytes via acetylation of p65. J Immunol 179:7101-7109.

Simard AR, Soulet D, Gowing G, Julien JP, Rivest S (2006) Bone marrowderived microglia play a critical role in restricting senile plaque formation in Alzheimer's disease. Neuron 49:489-502.

Singh I, Pahan K, Khan M, Singh AK (1998) Cytokine-mediated induction of ceramide production is redox-sensitive. Implications to proinflammatory cytokine-mediated apoptosis in demyelinating diseases. J Biol Chem 273:20354-20362.

Stalder AK, Ermini F, Bondolfi L, Krenger W, Burbach GJ, Deller T, Coomaraswamy J, Staufenbiel M, Landmann R, Jucker M (2005) Invasion of hematopoietic cells into the brain of amyloid precursor protein transgenic mice. J Neurosci 25:11125-11132.

Sun YX, Minthon L, Wallmark A, Warkentin S, Blennow K, Janciauskiene S (2003) Inflammatory markers in matched plasma and cerebrospinal fluid from patients with Alzheimer's disease. Dement Geriatr Cogn Disord 16:136-144.

Szekely CA, Thorne JE, Zandi PP, Ek M, Messias E, Breitner JC, Goodman SN (2004) Nonsteroidal anti-inflammatory drugs for the prevention of Alzheimer's disease: a systematic review. Neuroepidemiology 23:159-169.

Szekely CA, Town T, Zandi PP (2007) NSAIDs for the chemoprevention of Alzheimer's disease. Subcell Biochem 42:229-248.

Tan J, Town T, Paris D, Mori T, Suo Z, Crawford F, Mattson MP, Flavell RA, Mullan M (1999) Microglial activation resulting from CD40-CD40L interaction after beta-amyloid stimulation. Science 286:2352-2355.

Tan J, Town T, Crawford F, Mori T, DelleDonne A, Crescentini R, Obregon D, Flavell RA, Mullan MJ (2002) Role of CD40 ligand in amyloidosis in transgenic Alzheimer's mice. Nat Neurosci 5:1288-1293.

Tarkowski E, Liljeroth AM, Minthon L, Tarkowski A, Wallin A, Blennow K (2003) Cerebral pattern of pro- and anti-inflammatory cytokines in dementias. Brain Res Bull 61:255-260. 
Tohgi H, Abe T, Yamazaki K, Murata T, Ishizaki E, Isobe C (1999) Alterations of 3-nitrotyrosine concentration in the cerebrospinal fluid during aging and in patients with Alzheimer's disease. Neurosci Lett 269:52-54.

Town T, Laouar Y, Pittenger C, Mori T, Szekely CA, Tan J, Duman RS, Flavell RA (2008) Blocking TGF-beta-Smad2/3 innate immune signaling mitigates Alzheimer-like pathology. Nat Med 14:681-687.

Van Antwerp DJ, Martin SJ, Kafri T, Green DR, Verma IM (1996) Suppression of TNF-alpha-induced apoptosis by NF-kappaB. Science 274:787-789.

Walsh S, Aisen PS (2004) Inflammatory processes and Alzheimer's disease. Expert Rev Neurother 4:793-798.

Wang CY, Mayo MW, Baldwin AS Jr (1996) TNF- and cancer therapyinduced apoptosis: potentiation by inhibition of NF-kappaB. Science 274:784-787.

White JA, Manelli AM, Holmberg KH, Van Eldik LJ, Ladu MJ (2005)
Differential effects of oligomeric and fibrillar amyloid-beta 1-42 on astrocyte-mediated inflammation. Neurobiol Dis 18:459-465.

Wiesner DA, Dawson G (1996) Staurosporine induces programmed cell death in embryonic neurons and activation of the ceramide pathway. J Neurochem 66:1418-1425.

Won JS, Im YB, Khan M, Singh AK, Singh I (2004) The role of neutral sphingomyelinase produced ceramide in lipopolysaccharide-mediated expression of inducible nitric oxide synthase. J Neurochem 88:583-593.

Xie Z, Smith CJ, Van Eldik LJ (2004) Activated glia induce neuron death via MAP kinase signaling pathways involving JNK and p38. Glia 45:170-179.

Zeng C, Lee JT, Chen H, Chen S, Hsu CY, Xu J (2005) Amyloid-beta peptide enhances tumor necrosis factor-alpha-induced iNOS through neutral sphingomyelinase/ceramide pathway in oligodendrocytes. J Neurochem 94:703-712. 